\title{
INL Green Building Strategy
}

\author{
Jennifer Dalton \\ Ernest Fossum
}

May 2005

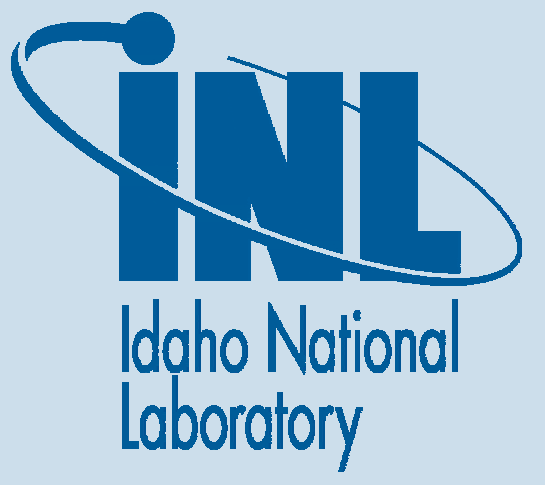

The INL is a U.S. Department of Energy National Laboratory operated by Battelle Energy Alliance 

INL/EXT-05-00331

\section{INL Green Building Strategy}

Jennifer Dalton

Ernest Fossum

May 2005

Idaho National Laboratory

Idaho Falls, Idaho 83415

Prepared for the U.S. Department of Energy Under DOE Idaho Operations Office Contract DE-AC07-05ID14517 



\section{EXECUTIVE SUMMARY}

Green buildings, also known as sustainable buildings, resource efficient buildings, and high performance buildings, are structures that minimize the impact on the environment by using less energy and water, reducing solid waste and pollutants, and limiting the depletion of natural resources.

As Idaho National Laboratory (INL) becomes the nation's premier nuclear energy research laboratory, the physical infrastructure will be established to help accomplish the mission. This infrastructure, particularly the buildings, should incorporate green design features in order to be environmentally responsible and reflect an image of progressiveness and innovation to the public and prospective employees. With this in mind, the recommendations described in this strategy are intended to form the INL foundation for green building standards.

The recommendations in this strategy are broken down into three levels: Baseline Minimum, Leadership in Energy and Environmental Design (LEED) Certification, and Innovative.

- $\quad$ Baseline Minimum features should be included in all new occupied buildings no matter what the purpose or size. These features do not require significant research, design, or capital costs and yet they can reduce Operation and Maintenance (O\&M) costs and produce more environmentally friendly buildings.

- $\quad$ LEED Certification features are more aggressive than the Baseline Minimums in that they require documentation, studies, and/or additional funding. Combined with the Baseline Minimums, many of the features in this level will need to be implemented to achieve the goal of LEED certification. LEED Silver certification should be the minimum goal for all new buildings (including office buildings, laboratories, cafeterias, and visitor centers) greater than 25,000 square feet or a total cost of $\$ 10$ million.

- Innovative features can also contribute to LEED certification, but are less mainstream than those listed in the previous two levels. These features are identified as areas where INL can demonstrate leadership but they could require significant upfront cost, additional studies, and/or development.

Appendix A includes a checklist summary of the INL Green Building Strategy that can be used as a tool during the design process when considering which green building features to include. It provides a quick reference for determining which strategies have lower or no increased capital cost, yield lower O\&M costs, increase employee productivity, and contribute to LEED certification. 


\section{CONTENTS}

EXECUTIVE SUMMARY

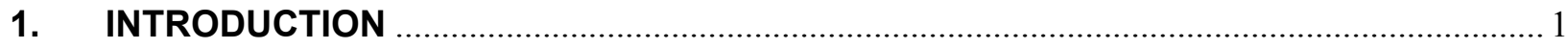

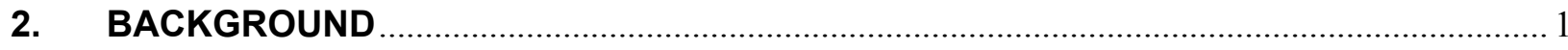

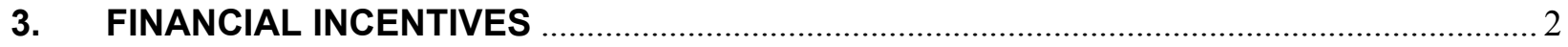

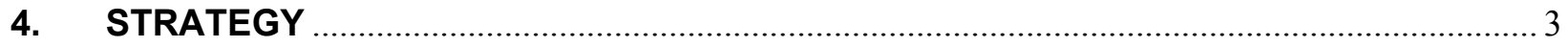

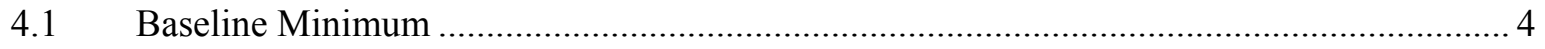

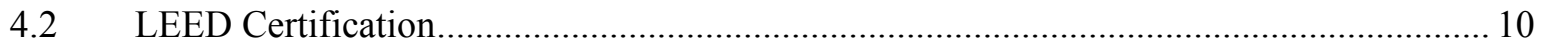

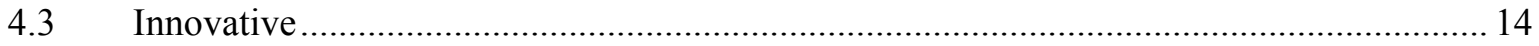

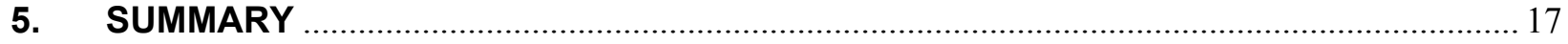

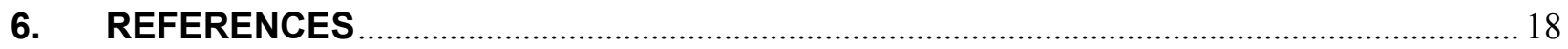

Appendix A INL Green Building Strategy Checklist .................................................................... 19

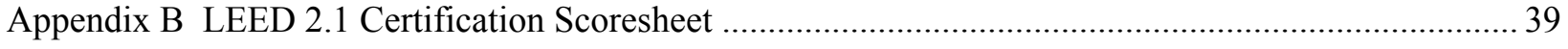




\section{ACRONYMS}

\begin{tabular}{ll} 
ASHRAE & American Society of Heating, Refrigerating and Air Conditioning Engineers \\
CFC & Chlorofluorocarbons \\
CNG & Compressed Natural Gas \\
CO $_{2}$ & Carbon Dioxide \\
DOE & Department of Energy \\
GSA & U.S. General Services Administration \\
HCFC & Hydrochlorofluorocarbons \\
HVAC & Heating, Ventilation and Air Conditioning \\
IAQ & Indoor Air Quality \\
INL & Idaho National Laboratory \\
LED & Light Emitting Diode \\
LEED & Leadership in Energy and Environmental Design \\
LNG & Liquefied Natural Gas \\
Low-E & Low-emittance \\
M\&V & Measurement and Verification \\
O\&M & Operation and Maintenance \\
USGBC & United States Green Building Council \\
VOCs & Volatile Organic Compounds \\
\hline
\end{tabular}




\section{INL Green Building Strategy}

\section{INTRODUCTION}

The Department of Energy's (DOE) vision for the new Idaho National Laboratory (INL) is that it will enhance the nation's energy security by becoming the preeminent, world-class, nuclear research development and demonstration laboratory within 10 years. To achieve this goal, additional state-of-theart facilities will be required at INL.

INL will be comprised of three modern campuses that are necessary to achieve the DOE objectives. These campuses include the Science and Technology Complex, Reactor Technology Complex, and Materials and Fuels Complex. As it moves forward in the design and construction of new facilities, INL should demonstrate its environmental stewardship commitment by incorporating appropriate "green building" elements in the design specifications.

Construction of new facilities can be achieved through various funding mechanisms including private sector funding, university funding, and government line-item funding; therefore, it is important to clarify INL green-building concepts in advance.

The goal of this document is to establish the foundation at INL for the design and construction of greener high-performance buildings. The focus is on the technical and functional requirements (T\&FR) that address the environmental issues specific to this geographical region (e.g., water efficiency), as well as those that are good economical sustainable practices (e.g., energy efficiency, material minimization). Overall, INL can improve the way its buildings are designed and constructed by keeping in mind the goals of reducing solid waste, the production of toxins, and the depletion of resources.

\section{BACKGROUND}

In the U.S., commercial and residential buildings consume one-third of the energy and two-thirds of all electricity according to DOE. Buildings are also large consumers of natural resources: they use $40 \%$ of the raw stone, sand, and gravel; $25 \%$ of the wood harvest; and $16 \%$ of the water. The goal of green or high performance buildings is to use holistic design to lessen a building's impact on the environment.

For example, green buildings reduce water and energy consumption, minimize consumption of virgin materials, reduce waste going to landfills, and lessen the embodied energy of the building materials. In addition, healthy buildings that breathe (are efficiently ventilated with fresh air) and only use interior materials that do not off-gas harmful pollutants, such as Volatile Organic Compounds (VOCs), provide healthy environments for their occupants and thus eliminate sick building syndrome.

As INL works to advance nuclear energy as an alternative to fossil fuel consumption, it is particularly important to showcase INL's progressiveness, innovativeness, and environmentally responsible character. This is particularly evident when designing and constructing new buildings.

Leadership in Energy and Environmental Design (LEED) certification by the U.S. Green Building Council (USGBC) is the industry standard for the design and construction of green buildings. While recent studies show that the upfront investment required for a LEED certification is roughly $2 \%$ of the capital costs, the cost premium is easily recovered in the reduced energy and operating costs of the building over its life. 
Multiple federal agencies have adopted LEED as a minimum performance standard for new buildings. Federal agencies were directed by President Clinton via Executive Order 13123 in 1999 to apply sustainable building practices. This Order, "Greening the Government Through Efficient Energy Management," requires: "DOE and GSA, in consultation with DOE and EPA, shall develop sustainable design principles. Agencies shall apply such principles to the siting, design, and construction of new facilities."

The U.S. General Services Administration (GSA), the U.S. Environmental Protection Agency (EPA), and the U.S. Navy have adopted the LEED rating system for new buildings. The U.S. Air Force requires LEED design elements, but self certifies, rather than submitting packages to the USGBC for LEED certification. National Aeronautics and Space Administration (NASA) has adopted the LEED structure as a goal, and the Departments of State and Veterans Affairs have adopted specific items from the LEED certification checklist. DOE is expected to announce the adoption of LEED-like criteria with specific emphasis on energy and water efficiency in 2005. DOE currently requires a Sustainable Design Report for new DOE buildings.

Within the DOE complex, five sites have achieved or are in the process of receiving LEED certification on campus buildings. These buildings include National Renewable Energy Lab's new Science and Technology Facility, Lawrence Berkeley National Laboratory's Molecular Foundry Building, Argonne National Laboratory's Central Supply Facility, Oak Ridge National Laboratory's East Campus Modernization Project office/research building, and Sandia National Laboratories' Center for Integrated Nano-Technologies and the Microsystems and Engineering Systems Applications Laboratory.

The federal government is adopting new policy that favors reduced Life Cycle Cost over Lowest First Cost in new building design and construction. The use of green building design principles through LEED will result in buildings with a lower Life Cycle Cost to the federal government over the life of the facility.

\section{FINANCIAL INCENTIVES}

The questions of how much green buildings cost and whether they cost more than conventional construction are usually the first to be asked. While there are no straightforward answers to these questions since each project is unique, various studies have shown that green buildings typically have lower operation and management (O\&M) costs; thus, the potential higher capital costs are offset in only a few years.

A number of studies have recently been undertaken to quantify the price difference of a building with green features versus the building without green features.

A study done for the State of California looked at the cost of 33 green buildings compared to the conventional, non-green design of the same buildings (Kats et al. 2003). This study found that the average premium for a green building was less than $2 \%$ (or \$3-5/square foot) more than the conventional design. This increase was mostly attributed to increased architectural and engineering support; however, in general, the sooner green goals are established in the design process, the lower these costs are. The total life cycle savings (including energy, water, waste, and improved productivity and health) were found to be 10 times the average initial investment for design and construction.

In fact, new buildings designed to be energy efficient often operate on $20 \%$ of the energy used by corresponding older existing facilities. Older facilities can usually be retrofit to save around $30 \%$ of 
existing energy used (Capehart et al, 1994). Clearly, adopting energy efficient design features into new building designs will provide direct O\&M cost savings.

In 2004, Davis Langdon, a cost planning and sustainable design management firm, conducted an in-depth study and found that construction costs varied greatly within the same building type (academic buildings, laboratories, and libraries), but that there was no statistically significant difference between the construction cost of a LEED building and a non-LEED building (Matthiessen \& Morris).

An additional beneficial byproduct of green buildings, although difficult to quantify, is higher productivity and reduced absenteeism because the buildings are more healthy and comfortable for occupants. These are important considerations when the goal is to attract and retain the best people at INL.

Despite the potential of slightly higher capital costs, green buildings can yield O\&M savings and improve employee productivity that can pay back this difference in a few years.

\section{STRATEGY}

The recommendations in this document are broken down into three levels: Baseline Minimum, LEED Certification, and Innovative.

Baseline Minimum strategies should be included in all new occupied buildings no matter what the purpose or size. They should also be considered during renovations of existing buildings. They do not require significant research, design, or up-front costs and yet they can reduce maintenance costs and make a building more environmentally friendly.

LEED Certification strategies are more aggressive than the Baseline Minimums in that they require documentation, studies, and/or additional funding. Combined with the Baseline Minimums, many of the features in this level will need to be implemented to achieve LEED certification. LEED Silver certification should be the minimum goal for all new INL buildings (including office buildings, laboratories, cafeterias, and visitor centers) greater than 25,000 square feet or a total cost of \$10 million. Process buildings should apply these principles but may not qualify for certification because the LEED rating system is designed for more conventional buildings such as those mentioned previously.

Innovative strategies can also contribute to LEED certification but are less mainstream than those listed in the previous two levels. These are areas where INL can demonstrate leadership but they may require significant upfront cost, additional studies, and/or development.

The three levels, Baseline Minimum, LEED Certification, and Innovative, are discussed in detail in the next three sections. In each of these sections, the recommended design strategies are organized into the following five LEED categories:

- $\quad$ Sustainable Sites - Geared towards minimizing site disturbance; using responsible landscaping; promoting the use of commuting and alternative transportation such as bicycles, mass transit; and alternatively fueled (hybrid and Compressed Natural Gas [CNG]/Liquified Natural Gas [LNG]) vehicles; and reducing light pollution.

- Water Efficiency - Covers design features that reduce potable water consumption and/or wastewater treatment demand.

- $\quad$ Energy \& Atmosphere - Promotes energy efficiency and renewable energy consumption. 
- Materials \& Resources - Calls for efficient material use through the specification of recycled, rapidly renewable, salvaged, and local building materials during design and the recycling of building waste during occupancy. The goal is to minimize the demand for virgin materials and the harmful environmental effects associated with extracting and processing them, while lowering the total embodied energy content of the building.

- Indoor Environmental Quality - Promotes the health and productivity of building occupants by providing well ventilated and thermally comfortable interior spaces, materials that do not off-gas, and daylight and views.

The three levels and the recommended design strategies organized into the five LEED categories are summarized in Appendix A, which can be used as a quick reference tool to determine whether the individual strategies provide capital cost savings, provide O\&M savings, increase employee productivity, and contribute to LEED certification.

It is recommended that this document be reviewed and updated as necessary to reflect the latest green building recommendations. At the time of publication, the most current version is LEED 2.1, but LEED 2.2 and LEED 3.0 are expected in the near future. It will also be important to update the strategies in each level to make sure they coincide with the current state of the technology and to move strategies from the LEED Certification level to the Baseline Minimum level and from the Innovative level to the LEED Certification level as they become more feasible and/or prevalent.

\subsection{Baseline Minimum}

The recommended actions outlined in this section comprise a strategy to include minimum design features that result in an energy and resource efficient facility. These strategies should be included in all new occupied buildings no matter what the purpose or size. They should also be considered during renovations of existing buildings. They do not require significant research, design, or up-front costs and yet they can reduce maintenance costs and make a building more environmentally friendly.

\subsubsection{General}

These strategies are key to an efficient high-performance design process to ensure that goals for buildings are identified to all stakeholders early in the design process in order to minimize costs.

\section{Integrated Design Team}

- $\quad$ Assemble an integrated design team from multiple disciplines early in the design process

- $\quad$ At a minimum include the building owners, architects, building design engineers, landscape designers, O\&M staff, general contractor, key sub-contractors, cost consultants, and future occupants

- $\quad$ Use a kick-off meeting at the beginning of the design process to establish the goals of all stakeholders and identify the responsible parties

- $\quad$ Have an individual experienced with the integrated design process participate with the facilitation of the meeting 


\subsubsection{Sustainable Sites}

These features are geared towards minimizing site disturbance; using responsible landscaping; promoting the use of commuting and alternative transportation such as bicycles, mass transit, and alternatively fueled vehicles; and reducing light pollution.

\section{Site Selection}

- $\quad$ Select a building site for new construction that meets the following requirements:

- Is not considered prime farm land as defined by the U.S. Department of Agriculture

- $\quad$ Does not provide habitat for threatened or endangered species

- $\quad$ Is at least 5 feet above the 100-year flood plain

- $\quad$ Is not within 100 feet of a wetland

\section{Landscaping}

- $\quad$ Artfully incorporate existing native vegetation into new landscape plans to minimize site disturbance and reduce landscape maintenance costs

- $\quad$ Select native species to minimize/eliminate irrigation, mowing, and fertilizing

- Design for drip irrigation in preference over traditional sprinklers to conserve water

\section{Alternative Transportation}

- $\quad$ Offer covered bicycle racks to keep bikes protected from the weather and encourage bike riding over personal vehicle use

- $\quad$ Plan for green belt access at town facilities where geographically applicable

- $\quad$ Plan for bus and taxi access during building design to promote and encourage public transit use as an alternative to personal vehicles

- $\quad$ Clearly mark INL bus stops and INL taxi stands

- $\quad$ Provide weather shelters for passengers awaiting pick-up

- $\quad$ Post bus schedules and taxi directions in strategic locations

- $\quad$ Offer preferred parking (signage) for personal vehicles with two or more passengers (carpoolers), personal hybrid vehicles, and LNG/CNG fueled vehicles

\section{Light pollution reduction}

- Use fixtures compatible with light pollution reduction (flat lenses and minimal wattage) to reduce unnecessary light, eliminate light leaving the area, and lessen the impact of human development on nocturnal environments

\subsubsection{Water Efficiency} demand.

These strategies cover features that reduce potable water consumption and/or wastewater treatment 
The primary benefits of saving water include conserving resources during times of drought at INL and reducing the amount of water used, thus saving the costs to pump, treat, and dispose water. INL currently uses more than 1.1 billion gallons of water each year at a cost of more than $\$ 750 \mathrm{~K}$, which includes most wastewater treatment costs. Currently, the average cost of water at the point of use is $\$ .0006$ per gallon. It is usually not cost effective to retrofit existing systems to save water; however, it is very cost effective to design water efficiency into new building designs and major upgrades.

\section{Low water fixtures}

- $\quad$ Specify low-flow faucets, shower heads, and fixtures that are rated at high performance and low maintenance to reduce potable water consumption

- $\quad$ Examples of desired features include long lasting ceramic valves on faucets and glazed trapways on water closets

- Use motion sensor controls in lavatory faucets to reduce potable water consumption by as much as $75 \%$ over traditional faucets

\subsubsection{Energy \& Atmosphere}

These strategies promote energy efficiency and renewable energy consumption.

INL uses more than $191 \mathrm{~K}$ megawatt hours of electricity each year at an annual cost of $\$ 8.8$ million that calculates to more than $\$ .04$ per kilowatt hour. Most retrofit projects that replace inefficient lighting, HVAC, and compressed air systems provide cost paybacks in less than five years. In some cases, paybacks for particularly inefficient systems have been less than two months. Most of the recommendations given in this section have little or no additional cost attached to their implementation. Any minor additional costs would easily be paid back within the first few years of building occupancy.

\section{Energy Efficiency}

- $\quad$ For new construction, design the building envelope and building systems (HVAC, lighting, etc.) to exceed ANSI/ASHRAE/IESNA 90.1-2004 (ASHRAE 90.1), Energy Standard for Buildings Except Low-Rise Residential, by $10 \%$ at a minimum. Significant renovations should be designed to meet ASHRAE 90.1. ASHRAE 90.1 is the accepted standard for quantifying a building's energy savings.

- $\quad$ Use an approved energy modeling software package to verify the results

- Orient the building on its site to maximize solar gain in the winter and minimize solar gain in the summer

- Use deciduous trees on the southwest side of the building to provide shade in the summer and solar heat gain in the winter

- Locate driveways, parking, entrances, and loading docks on the south side of the building when practical to avoid snow and ice build-up naturally without the use of deicers

- $\quad$ Provide metering sufficient to enable measurement and verification (M\&V) of energy used in lighting and HVAC systems at a minimum to ensure the building is performing as designed and constructed

- $\quad$ Metering should be tied into and be fully compatible with the automated building control system 
- $\quad$ Specify windows with a low-emittance (low-E) coating to reduce unwanted heat gain in the summer and reduce heat loss in the winter

- $\quad$ Low-E coatings are lightly transparent and are virtually invisible, but have a high reflectance (low emittance) to long wavelength infrared radiation. This reduces long-wavelength radiative heat transfer between glazing layers by a factor of 5 to 10 , thereby reducing total heat transfer between glazing layers. Low-E coatings reduce both the heat transfer into the building during the summer and heat transfer out of the building during the winter

- $\quad$ Purchase high efficiency (e.g., Energy Star) appliances to reduce electricity consumption

\section{Commissioning}

- Use third party commissioning of fundamental building systems such as the lighting and HVAC systems at a minimum to ensure that they are installed and perform as designed

- Third party commissioning is defined as an individual, trained in commissioning, who is not directly associated with the operation or maintenance of the building or system being commissioned

\section{Efficient Lighting:}

- $\quad$ Specify T-8 fluorescent fixtures with electronic ballasts for general area lighting

- $\quad$ These are currently the standard for general area lighting and have the highest efficiency and light output per watt of the commonly accepted fluorescent lighting equipment for this category

- Increase task lighting and decrease general area lighting

- Increase the use of indirect lighting (T-5 fluorescent fixtures) for general area lighting

- Design for natural daylight where feasible to reduce artificial light

- $\quad$ Use light shelves and skylights to provide natural light at the required lighting levels in occupied spaces

- $\quad$ Specify ceiling paint or ceiling tiles with 0.9 or higher reflectance value in lighted work areas to reduce the need for artificial lighting

- $\quad$ Connect lighting systems to an automated building control system to allow scheduled programmable lighting control to all areas of the building

- $\quad$ Provide one-hour override control in regularly occupied, multi-use areas such as cubicle areas where employees could work intermittent hours outside of the normally programmed lighting schedule

- $\quad$ Consider occupancy sensors for all large work areas such as cubicle areas, server rooms, craft work areas, and inspection rooms that are not controlled by an automated building control system

- Install occupancy sensors in all common use areas such as restrooms, conference rooms, and copy rooms, and in private offices to turn the lights off when the spaces are unoccupied

- $\quad$ Connect outside lighting circuits to the automated building control system so that individual fixtures can be controlled and run on a programmed schedule

As an example, the entire system would be available for activation by the photocell controls between 5 a.m. and 10 p.m. During the remaining hours, only a minimum number of fixtures 
would be available to provide for safety and security lighting of entrances, the building perimeter, and limited parking areas

- $\quad$ Specify light emitting diode (LED) or self-illuminating exit lights

\section{Efficient HVAC Systems}

- Use programmable thermostats in existing buildings without automated building control systems

- $\quad$ Specify an economizer on roof-top units and economizer controls on all HVAC systems

- $\quad$ Use LNG for heating at the site

- $\quad$ Specify direct evaporative cooling whenever possible and indirect evaporative cooling where humidity could be an issue

- $\quad$ Evaporative cooling is very efficient in this dry climate and can typically be operated at savings of $70 \%$ over refrigerated cooling systems

- Use passive solar technologies to preheat outside air and hot water

Environmentally Friendly Refrigerants

- $\quad$ Do not use chlorofluorocarbon (CFC)-based refrigerants in building HVAC systems

\subsubsection{Materials \& Resources}

These strategies call for efficient material use through the specification of recycled, rapidly renewable, salvaged, and local building materials during design and the recycling of building waste during occupancy. The goal is to minimize the demand for virgin materials and the harmful environmental effects associated with extracting and processing them, while lowering the total embodied energy content of the building.

Promote Recycling

- At a minimum, incorporate recycling stations in building designs for all materials currently recycled

- $\quad$ Consider vertical chutes to assist with collection in multi-story buildings

- $\quad$ Provide for future expansion of the recycling program and the potential need for additional recycling collection containers and more frequent access

- $\quad$ Consider incorporating an organic composting area that allows the building occupants' organic waste to be used to fertilize landscaping or an employee vegetable garden

\section{Locally Available Materials}

- Give preference to regionally available materials (manufactured and/or extracted, harvested, or recovered within 500 miles of project location) in order to support the local economy and reduce the harmful environmental effects of transporting materials 
- Where feasible and cost effective, consider using an existing facility and renovate it appropriately instead of constructing a new building

\subsubsection{Indoor Environmental Quality}

These features promote the health and productivity of building occupants by providing well ventilated and thermally comfortable interior spaces, materials that do not off-gas, and daylight and views.

Construction Indoor Air Quality (IAQ)

- Prevent indoor air quality problems resulting from the construction/renovation process by:

- $\quad$ Controlling dirt, water, and contaminants from entering the HVAC system during construction through the use of Sheet Metal and Air Conditioning National Contractors Association (SMACNA) IAQ Guideline for Occupied Buildings under Construction, 1995, Chapter 3 or ASHRAE 52.2-1999, Method of Testing General Ventilation Air-Cleaning Devices for Removal Efficiency by Particle Size

- $\quad$ Conducting a minimum two-week building flush out before occupancy with new Minimum Efficiency Reporting Value (MERV) 13 filtration media at 100\% outside air

\section{Minimum IAQ Performance}

- $\quad$ Establish minimum IAQ performance using ASHRAE 62.1-2004, Ventilation for Acceptable Indoor Air Quality

\section{Thermal Comfort}

- $\quad$ Provide control and monitoring systems for humidity and temperature according to ASHRAE 55-2004, Thermal Comfort Conditions for Human Occupancy, to assure buildings offer occupants a workplace that is thermally comfortable

\section{Outdoor Designated Smoking Areas}

- $\quad$ Establish designated smoking areas outside the building that are away and downwind from entryways, operable windows, and air intakes

Air Change Effectiveness

- $\quad$ Use ASHRAE 129-1997, Measuring Air Change Effectiveness, to confirm ventilation effectiveness

\section{Low-Emitting Materials}

- Specify paints and coatings with low or no volatile organic compound (VOC) content and/or recycled content in order to reduce the quantity of indoor air contaminants and create a demand for recycled products 


\subsection{LEED Certification}

LEED Silver certification should be the minimum goal for all new buildings (including office buildings, laboratories, cafeterias, and visitor centers) greater than 25,000 square feet or a total cost of $\$ 10$ million. Process buildings, which typically house energy intensive systems or processes that are not directly part of the building systems, should apply these principles but may not qualify for certification because the LEED rating system is designed for more conventional buildings.

The design features included in this section are more aggressive than the Baseline Minimums in that they require documentation, studies, and/or additional funding. Combined with the Baseline Minimums, many of the strategies in this level will need to be implemented to achieve LEED Silver certification. However, incorporating these features may not necessarily be enough to reach certification. See Appendix B for more information. All of the strategies in this level should be considered for LEED Silver certification. The rationale for not including them in a building design should be documented.

\subsubsection{Sustainable Sites}

These features are geared towards minimizing site disturbance; using responsible landscaping; promoting the use of commuting and alternative transportation such as bicycles, mass transit, and alternatively fueled vehicles; and reducing light pollution.

\section{Erosion \& Sedimentation Control}

- $\quad$ Design a sediment and erosion control plan, specific to the site, that conforms to either the U.S. Environmental Protection Agency (EPA) Document No. EPA 832/R-92-005 (September 1992), "Storm Water Management for Construction Activities," Chapter 3, or the local erosion and sedimentation control standards and codes, whichever is more stringent

\section{Landscaping}

- Design a rainwater harvesting system with a gravity feed system for irrigation to minimize or even eliminate potable water use for irrigation since large flat roofs are a great resource for rainwater collection

\section{Stormwater Management}

- $\quad$ Consider porous pavement in parking lots and walkways in place of traditional impervious surfaces to reduce stormwater runoff and surface water contamination, and avoid the need for construction of stormwater retention ponds

\section{Reduced Site Disturbance}

- $\quad$ On greenfield sites, limit site disturbance including earthwork and clearing of vegetation to 40 feet beyond the building perimeter; 5 feet beyond primary road curbs, walkways, and main utility branch trenches; and 25 feet beyond constructed areas with permeable surfaces that require additional staging areas to limit compaction in the constructed area. 


\subsubsection{Water Efficiency}

demand.

These strategies cover features that reduce potable water consumption and/or wastewater treatment

Low water fixtures

- $\quad$ Use on-demand (also known as tankless) or point of use water heating rather than traditional water heaters at a consolidated remote location to reduce energy losses and water waste from long runs of hot water piping

- Consider dual flush water closets (also known as two-handle flush water closets) to reduce potable water consumption

- Consider interior gray water collection for black water use to reduce potable water consumption

- $\quad$ Gray water is recycled water from sinks, dishwashers, showers, and lavatories; and black water is a product of flushing water closets

- $\quad$ For example, plumb lavatory drains to provide water for flushing water closets or reclaim industrial process wastewater for flushing water closets

- Consider waterless urinals in place of traditional urinals to conserve water and reduce O\&M costs

- Waterless urinals are currently not allowed under Idaho Code, but there is an active campaign to change the code through the Idaho Organizing Group of the USGBC.

\subsubsection{Energy \& Atmosphere}

These strategies promote energy efficiency and renewable energy consumption.

The features outlined in this section will not provide the immediate payback of the Baseline Minimum features, but their adoption into building designs will result in additional cost savings while contributing towards a potential LEED certification.

\section{Energy Efficiency}

- $\quad$ For new construction, design the building envelope and building systems (HVAC, lighting, etc.) to exceed ANSI/ASHRAE/IESNA 90.1-2004 (ASHRAE 90.1), Energy Standard for Buildings Except Low-Rise Residential, by 15-60\%. Significant renovations should be designed to exceed ASHRAE 90.1 by $5-50 \%$. ASHRAE 90.1 is the accepted standard for quantifying a building's energy savings.

- $\quad$ Use an approved energy modeling software package to verify the results

- $\quad$ Use measurement and verification $(\mathrm{M} \& \mathrm{~V})$ for full spectrum of building systems to ensure the building is performing as designed and constructed

- $\quad$ At a minimum there should be metering equipment for the following end-uses: lighting systems and controls; constant and variable motor loads; variable frequency drive operation; chiller efficiency at various loads; cooling load; air and water economizer and heat recovery cycles; air distribution static pressures and ventilation air volumes; boiler efficiencies; building-related process energy systems and equipment; and indoor water risers and outdoor irrigation systems 
- $\quad$ The required metering to provide $M \& V$ can be part of the automated building control system

- Design building to maximize natural ventilation and eliminate the need for mechanical cooling

- $\quad$ Specify operable windows that can be opened by the building occupants when such operation will not adversely affect the building's HVAC system

- $\quad$ Investigate methods to design HVAC systems that will allow operable windows throughout the building to provide fresh air directly to occupants

\section{Environmentally Friendly Refrigerants (Ozone Protection)}

- $\quad$ Ensure that building HVAC and fire suppression systems do not use CFCs, HCFCs, or halons, all of which could harm the environment

\section{Commissioning}

- $\quad$ Expand the Fundamental Building Commissioning to include third party commissioning of all building systems from conceptual design through building occupancy.

\subsubsection{Materials \& Resources}

These strategies call for efficient material use through the specification of recycled, rapidly renewable, salvaged, and local building materials during design and the recycling of building waste during occupancy. The goal is to minimize the demand for virgin materials and the harmful environmental effects associated with extracting and processing them, while lowering the total embodied energy content of the building.

\section{Promote Recycling}

- Incorporate recycling systems in building design for a minimum of all LEED required materials (paper, corrugated cardboard, glass, plastics, and metals)

- $\quad$ Consider vertical chutes to assist with collection in multi-story buildings

- $\quad$ Provide for future expansion of the recycling program

\section{Waste Minimization}

- $\quad$ Design with waste minimization in mind using dimensions and configurations that will lead to less material waste during construction

- $\quad$ Develop methods to reduce waste during construction and divert waste from the landfill

- Donate reusable construction waste to local charities such as Habitat for Humanity when the material can be cost effectively reused or refurbished

- $\quad$ Provide bins at the construction site for separation and temporary storage of all construction waste to be reused, recycled, and salvaged/donated to the maximum amount feasible

- $\quad$ For example, concrete can be crushed and used as aggregate or fill

- $\quad$ Design with materials that serve multiple functions and allow for omission of layers (e.g., exposed duct work and finished concrete floors)

- Design using a flexible building floor plan to accommodate changing floor plans in the future 
- $\quad$ Use modular planning and flexible building infrastructures for HVAC, power, and communications

Salvaged Materials

- $\quad$ Specify salvaged materials over virgin materials with a goal of using salvaged materials for 5-10\% of the total building material budget

- Consider incorporation of INL historically relevant salvaged "landmarks" into new building designs

Recycled Materials

- $\quad$ Specify materials that contain post-consumer and post-industrial recycled content with a goal of using recycled materials for $5-10 \%$ of the total building budget

\section{Biobased and Rapidly Renewable Materials}

- $\quad$ Specify biobased products or products made from rapidly renewable materials

- $\quad$ Rapidly renewable materials are based on resources that can be re-generated in 10 years such as linoleum, cork, and rubber

- $\quad$ Performance tests should indicate that selected biobased or rapidly renewable materials will be as durable and maintainable as the commonly accepted materials they are replacing

\section{Certified Wood}

- $\quad$ Specify sustainably harvested wood as designated by the Forest Stewardship Council (FSC) or equivalent certification

\subsubsection{Indoor Environmental Quality}

These features promote the health and productivity of building occupants by providing well ventilated and thermally comfortable interior spaces, materials that do not off-gas, and daylight and views.

\section{Indoor Air Quality}

- Incorporate carbon dioxide $\left(\mathrm{CO}_{2}\right)$ monitoring systems into automated building control systems to control fresh air based on occupancy or $\mathrm{CO}_{2}$ levels

\section{Low-Emitting Materials}

- $\quad$ Specify products with low or no volatile organic compound (VOC) content for the following material types in order to reduce the quantity of indoor air contaminants that can be irritating and/or harmful to building occupants:

- $\quad$ Adhesives and Sealants- VOC content must be less than the current VOC content limits of South Coast Air Quality Management District (SCAQMD) Rule \#1168, and all sealants used as fillers must meet or exceed the requirements of the Bay Area Quality Management District Regulation 8, Rule 51 
- $\quad$ Paints and Coatings- VOC emissions from paints and coatings must not exceed the VOC and chemical component limits of Green Seal's Standard GS-11 requirements

- $\quad$ Carpet Systems- Must meet or exceed the requirements of the Carpet and Rug Institute's Green Label Indoor Air Quality Test Program

- Composite Wood and Agrifiber Products- Must contain no added urea-formaldehyde resins

- $\quad$ Avoid materials made from vinyl or PVC since the manufacturing process used to produce these materials involves hazardous and toxic substances

Daylight \& Views

- Achieve a minimum daylight factor (ratio of exterior illumination to interior illumination) of $2 \%$ for $75 \%$ of all spaces occupied for critical visual tasks

- $\quad$ Achieve a direct line of sight to exterior glazing for $90 \%$ of regularly occupied spaces

- $\quad$ Place copy centers, conference rooms, and other areas that are not regularly occupied in the non-view areas

Acoustics

- $\quad$ Consider noise and sound control when designing the building and selecting finish materials

\subsection{Innovative}

These strategies can also contribute to LEED certification, but are less mainstream than those listed in the previous sections. They are cutting edge technologies where INL can demonstrate leadership, but they may require significant upfront cost, additional studies, and/or development. They should be considered because INL can improve their performance and make these technologies more feasible.

For example, ground source heating and cooling is a proven technology, but requires significant upfront costs. Studies would be recommended before designing a new building around a ground source loop. Once the investment is made to design, install, and operate this system efficiently, and document the performance in one building, the cost to incorporate it into a second building would be much lower.

The following strategies should not be considered all encompassing; additional technologies should be considered for inclusion in this level as they become available.

\subsubsection{Sustainable Sites}

These features are geared towards minimizing site disturbance; using responsible landscaping; promoting the use of commuting and alternative transportation such as bicycles, mass transit, and alternatively fueled vehicles; and reducing light pollution.

Stormwater Collection

- Design the roof to be partially or entirely composed of a vegetated roof (also called a greenroof or ecoroof) using native plantings that do not require irrigation or maintenance 


\section{Alternative Transportation}

- Consider hydrogen as the primary fuel for intra-site transportation

- $\quad$ Should INL pursue production of hydrogen in Idaho, it is conceivable that INL could adopt a hydrogen-fueled infrastructure

\subsubsection{Water Efficiency} demand.

These strategies cover features that reduce potable water consumption and/or wastewater treatment Low water fixtures

- $\quad$ Consider composting water closets in place of traditionally plumbed water closets to reduce both potable water consumption and wastewater treatment demand

- $\quad$ These will likely require a basement for storage and treatment and therefore could be the most feasible in remote sites where connection to typical treatment facilities do not exist

- $\quad$ Consider onsite wastewater treatment such as a living machine for town facilities to reduce the load to the municipal wastewater treatment facility and increase the local aquifer recharge

\subsubsection{Energy \& Atmosphere}

These strategies promote energy efficiency and renewable energy consumption.

\section{Energy Efficiency}

- Use a heat exchanger in buildings with separate perimeter and core zones to take advantage of times when the perimeter zone is heating and the core zone is cooling

- Design for $100 \%$ natural ventilation to eliminate the demand for mechanical cooling

- $\quad$ Use high-performance glazed windows that are ultra-efficient

Alternative, Renewable Energy

- Consider fuel cells for the building's entire electrical demand

- $\quad$ Design for ground source heating and cooling

- $\quad$ These are particularly cost effective when used for cooling as well as heating, and are well suited to Idaho's cold winters as the heat source is beneath the ground and not subject to extremely cold weather temperatures

- Consider roof-top vertical axis wind generation for supplemental electrical power

- $\quad$ Consider photovoltaics for supplemental electrical power

Efficient HVAC Systems

- Specify radiant floor embedded heating and cooling to reduce the energy demand and promote occupancy comfort 


\section{Efficient Lighting}

- Use automatic sensors and dimming controls for daylit areas to allow artificial lights to slowly brighten and dim as the sun is covered and uncovered by clouds

- $\quad$ Creatively incorporate LEDs and T-5 lamps for task and indirect lighting sources

\subsubsection{Materials \& Resources}

These strategies call for efficient material use through the specification of recycled, rapidly renewable, salvaged, and local building materials during design and the recycling of building waste during occupancy. The goal is to minimize the demand for virgin materials and the harmful environmental effects associated with extracting and processing them, while lowering the total embodied energy content of the building.

\section{Local Materials}

- $\quad$ Specify materials that are manufactured and/or extracted, harvested, or recovered from Idaho in order to support the local economy and reduce the harmful environmental effects of transporting materials

\section{Life Cycle Cost Analysis}

- Use an accepted Life Cycle Cost analysis method like Triple Bottom Line for all building materials to select the most cost-effective product based on the cradle-to-grave cost

\section{Closed Loop Material Selection}

- Design for deconstruction so that the building can be disassembled into its constituent materials at the end of its lifetime

\subsubsection{Indoor Environmental Quality}

These features promote the health and productivity of building occupants by providing well ventilated and thermally comfortable interior spaces, materials that do not off-gas, and daylight and views.

\section{Occupancy Comfort}

- $\quad$ Provide individual lighting, temperature and air flow controls to occupants via desktop personal computers in order to increase employee comfort and promote productivity. 


\section{SUMMARY}

The document comprises the INL Green Building Strategy, which is intended to form the foundation for INL green building standards for all new construction and major renovations. The goal is to construct high-performance buildings that will have reduced impact on the environment, consume less energy and water to yield lower O\&M costs, and improve employee productivity.

The first level, Baseline Minimums, includes strategies that should be included as a matter of practice in all occupied buildings. LEED Silver Certification, the second level, covers strategies that should be incorporated into all buildings pursuing LEED certification in conjunction with the Baseline Minimums. The final level, Innovative, includes cutting edge technologies to be considered for progressive building designs. Each of these levels is constantly evolving to include the latest green building concepts.

The checklist in Appendix A is intended to serve as a tool during the design process of all future buildings. This checklist provides a quick reference to aid the user in determining which strategies have lower or no increased capital cost, yield lower O\&M costs, increase employee productivity, and contribute to LEED certification.

Appendix B shows the LEED 2.1 scoresheet with the points that could be achieved if the strategies identified in this document are followed. This appendix has been prepared to give an example of how this document can lead to a potential certification. The LEED 2.1 Reference Manual should be used during design to verify that the full criteria of the point have been met. 


\section{REFERENCES}

ASHRAE 52.2-1999, "Method of Testing General Ventilation Air-Cleaning Devices for Removal Efficiency by Particle Size," American Society of Heating, Refrigerating and Air Conditioning Engineers, 1999.

ASHRAE 55-2004, "Thermal Comfort Conditions for Human Occupancy," American Society of Heating, Refrigerating and Air Conditioning Engineers, 2004.

ASHRAE 62.1-2004, "Ventilation for Acceptable Indoor Air Quality," American Society of Heating, Refrigerating and Air Conditioning Engineers, 2004.

ASHRAE 90.1-2004, "Energy Standard for Buildings Except Low-Rise Residential," American Society of Heating, Refrigerating and Air Conditioning Engineers, 2004.

ASHRAE 129-1997, "Measuring Air Change Effectiveness," American Society of Heating, Refrigerating and Air Conditioning Engineers, 1997.

Capehart, B. L., Turner, W. C., and Kennedy, W. J., Guide to Energy Management, The Fairmont Press, 1994.

Fossum, E. L., "INEEL Annual Report on Energy and Utilities Management to the Federal Energy Management Program for reporting to Congress," November 15, 2004.

Kats, G., Alevantis, L., Berman, A., Mills, E., and Perlman, J., "The Costs and Financial Benefits of Green Buildings: A Report to California’s Sustainable Buildings Task Force,” October 2003.

Los Alamos National Laboratory, “LANL Sustainable Design Guide,” LA-UR 02-6914, December 2002.

Matthiessen, L.F., and Morris, P., Costing Green: A Comprehensive Cost Database and Budgeting Methodology, Davis Langdon, July 2004.

Steven Winter Associates, “GSA LEED Cost Study,” GS-11P-99-MAD-0565, October 2004.

Thumann A., Optimizing HVAC Systems, Fairmont Press, Inc., 1987.

U.S. Green Building Council, LEED 2.1 Reference Manual for New Construction and Major Renovations (LEED-NC), Version 2.1, 2nd Edition, May 2003. 
Appendix A

INL Green Building Strategy Checklist 


\section{Appendix A}

\section{INL Green Building Strategy Checklist}

This checklist is intended to provide a quick reference tool summarizing whether the individual strategies in the INL Green Building Strategy provide capital cost savings, provide O\&M savings, increase employee productivity, and contribute to LEED certification. The criteria used in this checklist are defined as follows:

Lower capital cost

No increased capital cost

Reduced O\&M Costs

Increase Productivity

Fulfill LEED Prerequisite

Fulfill LEED Credit

LEED Prerequisite/Credit
This strategy has a lower capital cost than the existing building practice

This strategy has a capital cost that is the same or not significantly higher than the conventional building practice

This strategy will yield operating \& maintenance costs that are lower than those that would be seen if the comparable non-green building practice was followed

This strategy has the ability to increase employee productivity by creating a better facility with a more comfortable working environment

This strategy fulfills (shown on the checklist as an "F") or contributes (shown as a "C") to a LEED prerequisite. These prerequisites are baseline requirements for all buildings pursuing LEED certification; they do not add points towards certification.

This strategy fulfills (shown on the checklist as an "F") or contributes (shown as a "C") to a LEED credit

This indicates which LEED prerequisite and/or credit that the strategy will contribute to and/or fulfill according to the numbering system used in the LEED 2.1 Registered Project Checklist (see Appendix B) and the LEED 2.1 Reference Manual:

$\mathrm{SS}=$ Sustainable Sites

$\mathrm{WE}=$ Water Efficiency

$\mathrm{EA}=$ Energy $\&$ Atmosphere

$\mathrm{MR}=$ Materials \& Resources

$\mathrm{EQ}=$ Indoor Environmental Quality.

For example, LEED EA PR 1 indicates LEED Energy and Atmosphere Prerequisite 1, and LEED MR CR 3.1 indicates LEED Materials and Resources Credit 3.1. 
Appendix A 


\section{BASELINE MINIMUM}

\begin{tabular}{|c|c|c|c|c|c|c|c|}
\hline Green INL Strategy for Baseline Minimum & 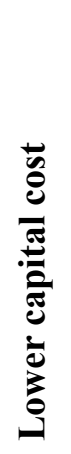 & 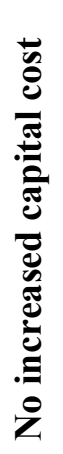 & 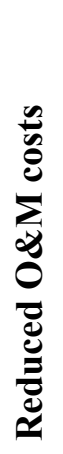 & 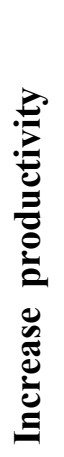 & 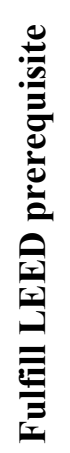 & 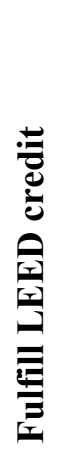 & 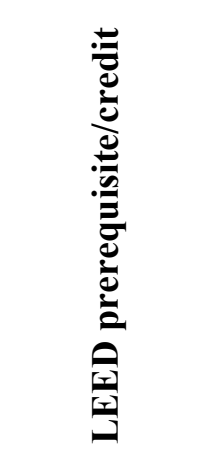 \\
\hline \multicolumn{8}{|l|}{ General } \\
\hline \multicolumn{8}{|l|}{ Integrated Design Team } \\
\hline $\begin{array}{l}\text { - Assemble an integrated design team from multiple } \\
\text { disciplines early in the design process }\end{array}$ & & $\checkmark$ & $\checkmark$ & & & & \\
\hline $\begin{array}{l}\text { - Use a kick-off meeting at the beginning of the design } \\
\text { process to establish the goals of all stakeholders and } \\
\text { identify the responsible parties }\end{array}$ & & $\checkmark$ & $\checkmark$ & & & & \\
\hline \multicolumn{8}{|l|}{ Sustainable Sites } \\
\hline \multicolumn{8}{|l|}{ Site Selection } \\
\hline $\begin{array}{l}\text { - Select a building site for new construction that meets the } \\
\text { following requirements: }\end{array}$ & & $\checkmark$ & & & & $\mathrm{F}$ & SS CR 1 \\
\hline - Is not considered prime farm land & & $\checkmark$ & & & & $\mathrm{C}$ & SS CR 1 \\
\hline $\begin{array}{l}\text { - Does not provide habitat for threatened or } \\
\text { endangered species }\end{array}$ & & $\checkmark$ & & & & $\mathrm{C}$ & SS CR 1 \\
\hline - Is at least 5 feet above the 100 -year flood plain & & $\checkmark$ & & & & $\mathrm{C}$ & SS CR 1 \\
\hline - Is not within 100 feet of a wetland & & $\checkmark$ & & & & $\mathrm{C}$ & SS CR 1 \\
\hline \multicolumn{8}{|l|}{ Landscaping } \\
\hline $\begin{array}{l}\text { - Artfully incorporate existing native vegetation into new } \\
\text { landscape plans }\end{array}$ & $\checkmark$ & & $\checkmark$ & & & $\mathrm{C}$ & $\begin{array}{l}\text { WE CR } 1.1, \\
\text { WE CR } 1.2\end{array}$ \\
\hline
\end{tabular}

$\mathrm{C}=$ Contributes

$\mathrm{CR}=$ Credit

$\mathrm{EA}=$ Energy \& Atmosphere

$\mathrm{EQ}=$ Indoor Environmental Quality

$\mathrm{F}=$ Fulfills
$\mathrm{MR}=$ Materials \& Resources

$\mathrm{PR}=$ Prerequisite

$\mathrm{SS}=$ Sustainable Sites

$\mathrm{WE}=$ Water Efficiency

$\checkmark=$ Meets criteria 


\begin{tabular}{|c|c|c|c|c|c|c|c|}
\hline Green INL Strategy for Baseline Minimum & 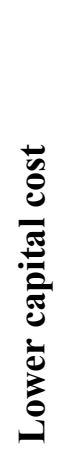 & 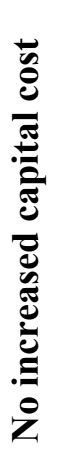 & 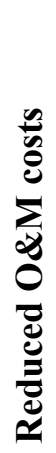 & 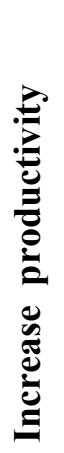 & 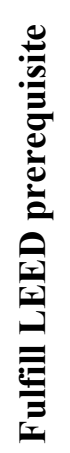 & 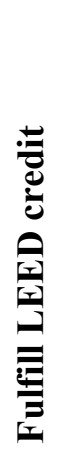 & 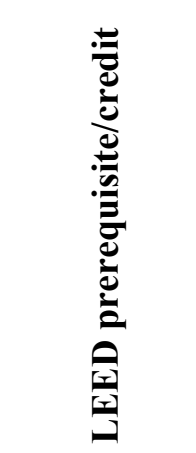 \\
\hline - Select native species & $\checkmark$ & & $\checkmark$ & & & $\mathrm{C}$ & $\begin{array}{l}\text { WE CR } 1.1, \\
\text { WE CR } 1.2\end{array}$ \\
\hline - Design for drip irrigation & & & $\checkmark$ & & & $\mathrm{C}$ & WE CR 1.1 \\
\hline \multicolumn{8}{|l|}{ Alternative Transportation } \\
\hline - Offer covered bicycle racks & & $\checkmark$ & & $\checkmark$ & & $\mathrm{C}$ & SS CR 4.2 \\
\hline - Plan for green belt access at town facilities & & & & $\checkmark$ & & & \\
\hline - Plan for bus and taxi access during building design & & $\checkmark$ & & $\checkmark$ & & & \\
\hline - Clearly mark INL bus stops and INL taxi stands & & $\checkmark$ & & $\checkmark$ & & & \\
\hline $\begin{array}{l}\text { - Provide weather shelters for passengers awaiting pick- } \\
\text { up }\end{array}$ & & & & $\checkmark$ & & & \\
\hline $\begin{array}{l}\text { - Post bus schedules and taxi directions in strategic } \\
\text { locations }\end{array}$ & & $\checkmark$ & & $\checkmark$ & & & \\
\hline $\begin{array}{l}\text { Offer preferred parking for personal vehicles with two } \\
\text { or more passengers, personal hybrid vehicles, and } \\
\text { LNG/CNG fueled vehicles }\end{array}$ & & $\checkmark$ & & & & $\mathrm{C}$ & SS CR 4.4 \\
\hline \multicolumn{8}{|l|}{ Light pollution reduction } \\
\hline - Use fixtures compatible with light pollution reduction & & $\checkmark$ & $\checkmark$ & & & $\mathrm{F}$ & SS CR 8 \\
\hline \multicolumn{8}{|l|}{ Water Efficiency } \\
\hline \multicolumn{8}{|l|}{ Low water fixtures } \\
\hline - Specify low-flow faucets, shower heads, and fixtures & & $\checkmark$ & $\checkmark$ & & & $\mathrm{C}$ & WE CR 3 \\
\hline
\end{tabular}

$$
\begin{aligned}
& \mathrm{C}=\text { Contributes } \\
& \mathrm{CR}=\text { Credit } \\
& \mathrm{EA}=\text { Energy \& Atmosphere } \\
& \mathrm{EQ}=\text { Indoor Environmental Quality } \\
& \mathrm{F}=\text { Fulfills }
\end{aligned}
$$

$\mathrm{MR}=$ Materials \& Resources

$\mathrm{PR}=$ Prerequisite

$\mathrm{SS}=$ Sustainable Sites

$\mathrm{WE}=$ Water Efficiency

$\checkmark=$ Meets criteria 


\begin{tabular}{|c|c|c|c|c|c|c|c|}
\hline Green INL Strategy for Baseline Minimum & 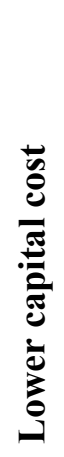 & 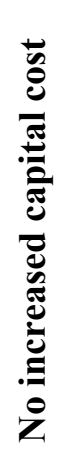 & 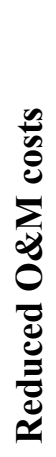 & 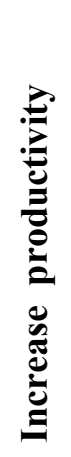 & 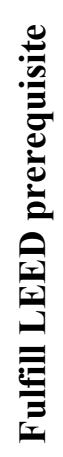 & 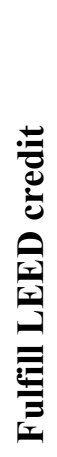 & 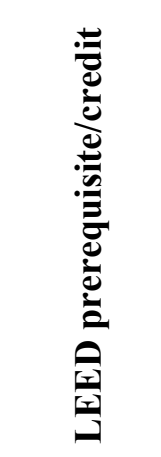 \\
\hline - Use motion sensor controls in lavatory faucets & & $\checkmark$ & $\checkmark$ & & & $\mathrm{C}$ & WE CR 3 \\
\hline \multicolumn{8}{|l|}{ Energy \& Atmosphere } \\
\hline \multicolumn{8}{|l|}{ Energy Efficiency } \\
\hline $\begin{array}{l}\text { - For new construction, design the building to exceed } \\
\text { ASHRAE } 90.1 \text { by } 10 \% \text {. Significant renovations should } \\
\text { be designed to meet ASHRAE } 90.1 \text {. }\end{array}$ & & & $\checkmark$ & & $\mathrm{F}$ & $\mathrm{F}$ & $\begin{array}{l}\text { EA PR 2, } \\
\text { EA CR } 1\end{array}$ \\
\hline $\begin{array}{l}\text { - Orient the building on its site to maximize solar gain in } \\
\text { the winter and minimize solar gain in the summer }\end{array}$ & & $\checkmark$ & $\checkmark$ & $\checkmark$ & $\mathrm{C}$ & $\mathrm{C}$ & $\begin{array}{l}\text { EA PR 2, } \\
\text { EA CR 1 }\end{array}$ \\
\hline $\begin{array}{l}\text { - Use deciduous trees on the southwest side of the } \\
\text { building }\end{array}$ & & $\checkmark$ & & $\checkmark$ & & & \\
\hline $\begin{array}{l}\text { - Locate driveways, parking, entrances, and loading docks } \\
\text { on the south side of the building }\end{array}$ & & $\checkmark$ & & $\checkmark$ & & & \\
\hline $\begin{array}{l}\text { - Provide metering sufficient to enable measurement \& } \\
\text { verification of energy used in lighting and HVAC } \\
\text { systems at a minimum }\end{array}$ & & & $\checkmark$ & & & $\mathrm{C}$ & EA CR 5 \\
\hline - Specify windows with a low-E coating & & $\checkmark$ & $\checkmark$ & $\checkmark$ & $\mathrm{C}$ & $\mathrm{C}$ & $\begin{array}{l}\text { EA PR 2, } \\
\text { EA CR } 1\end{array}$ \\
\hline - Purchase high efficiency appliances & & $\checkmark$ & $\checkmark$ & & $\mathrm{C}$ & $\mathrm{C}$ & $\begin{array}{l}\text { EA PR 2, } \\
\text { EA CR } 1\end{array}$ \\
\hline \multicolumn{8}{|l|}{ Commissioning } \\
\hline $\begin{array}{l}\text { - Use third party commissioning of fundamental building } \\
\text { systems }\end{array}$ & $\checkmark$ & & $\checkmark$ & $\checkmark$ & $\mathrm{F}$ & & EA PR 2 \\
\hline
\end{tabular}

$$
\begin{aligned}
& \mathrm{C}=\text { Contributes } \\
& \mathrm{CR}=\text { Credit } \\
& \mathrm{EA}=\text { Energy \& Atmosphere } \\
& \mathrm{EQ}=\text { Indoor Environmental Quality } \\
& \mathrm{F}=\text { Fulfills }
\end{aligned}
$$

$\mathrm{MR}=$ Materials \& Resources

$\mathrm{PR}=$ Prerequisite

$\mathrm{SS}=$ Sustainable Sites

$\mathrm{WE}=$ Water Efficiency

$\checkmark=$ Meets criteria 


\begin{tabular}{|c|c|c|c|c|c|c|c|}
\hline Green INL Strategy for Baseline Minimum & 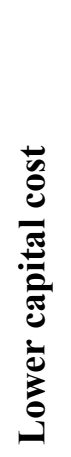 & 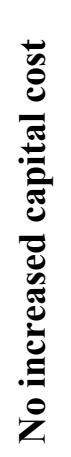 & 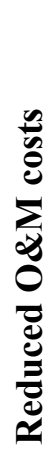 & 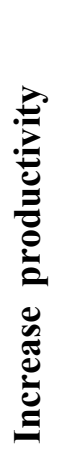 & 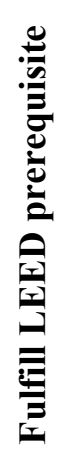 & 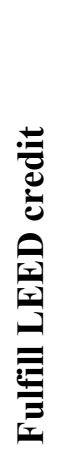 & 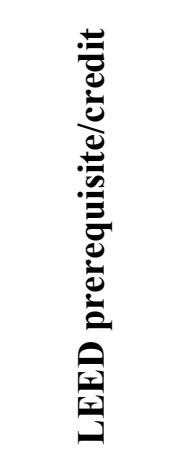 \\
\hline \multicolumn{8}{|l|}{ Efficient Lighting } \\
\hline $\begin{array}{l}\text { - Specify T-8 fluorescent fixtures with electronic ballasts } \\
\text { for general area lighting }\end{array}$ & & $\checkmark$ & $\checkmark$ & & $\mathrm{C}$ & $\mathrm{C}$ & $\begin{array}{l}\text { EA PR 2, } \\
\text { EA CR } 1\end{array}$ \\
\hline - Increase task lighting and decrease general area lighting & $\checkmark$ & & $\checkmark$ & $\checkmark$ & $\mathrm{C}$ & $\mathrm{C}$ & $\begin{array}{l}\text { EA PR 2, } \\
\text { EA CR } 1\end{array}$ \\
\hline $\begin{array}{l}\text { Increase the use of indirect lighting (T-5 fluorescent } \\
\text { fixtures) for general area lighting }\end{array}$ & & $\checkmark$ & $\checkmark$ & $\checkmark$ & $\mathrm{C}$ & $\mathrm{C}$ & $\begin{array}{l}\text { EA PR } 2 \\
\text { EA CR } 1\end{array}$ \\
\hline - Design for natural daylight where feasible & & $\checkmark$ & $\checkmark$ & $\checkmark$ & & $\mathrm{C}$ & EQ CR 8.1 \\
\hline $\begin{array}{l}\text { - Specify ceiling paint or ceiling tiles with } 0.9 \text { or higher } \\
\text { reflectance value in lighted work areas }\end{array}$ & & $\checkmark$ & $\checkmark$ & $\checkmark$ & & $\mathrm{C}$ & EQ CR 8.1 \\
\hline $\begin{array}{l}\text { - Connect lighting systems to an automated building } \\
\text { control system }\end{array}$ & & & $\checkmark$ & & $\mathrm{C}$ & $\mathrm{C}$ & $\begin{array}{l}\text { EA PR 2, } \\
\text { EA CR } 1\end{array}$ \\
\hline $\begin{array}{l}\text { - Consider occupancy sensors for all large work areas that } \\
\text { are not controlled by an automated building control } \\
\text { system }\end{array}$ & & $\checkmark$ & $\checkmark$ & & $\mathrm{C}$ & $\mathrm{C}$ & $\begin{array}{l}\text { EA PR } 2 \\
\text { EA CR } 1\end{array}$ \\
\hline $\begin{array}{l}\text { - Install occupancy sensors in all common use areas such } \\
\text { as restrooms, conference rooms, and copy rooms, and in } \\
\text { private offices }\end{array}$ & & $\checkmark$ & $\checkmark$ & & $\mathrm{C}$ & $\mathrm{C}$ & $\begin{array}{l}\text { EA PR } 2 \\
\text { EA CR } 1\end{array}$ \\
\hline $\begin{array}{l}\text { - Connect outside lighting circuits to the automated } \\
\text { building control system so that individual fixtures can } \\
\text { be controlled and run on a programmed schedule }\end{array}$ & & $\checkmark$ & $\checkmark$ & & $\mathrm{C}$ & $\mathrm{C}$ & $\begin{array}{l}\text { EA PR 2, } \\
\text { EA CR } 1\end{array}$ \\
\hline - Specify LED or self-illuminating exit lights & & $\checkmark$ & $\checkmark$ & & $\mathrm{C}$ & $\mathrm{C}$ & $\begin{array}{l}\text { EA PR } 2 \\
\text { EA CR } 1\end{array}$ \\
\hline
\end{tabular}

$\mathrm{C}=$ Contributes

$\mathrm{CR}=$ Credit

$\mathrm{EA}=$ Energy \& Atmosphere

$\mathrm{EQ}=$ Indoor Environmental Quality

$\mathrm{F}=$ Fulfills
$\mathrm{MR}=$ Materials \& Resources

$\mathrm{PR}=$ Prerequisite

$\mathrm{SS}=$ Sustainable Sites

$\mathrm{WE}=$ Water Efficiency

$\checkmark=$ Meets criteria 


\begin{tabular}{|c|c|c|c|c|c|c|c|}
\hline Green INL Strategy for Baseline Minimum & 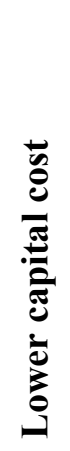 & 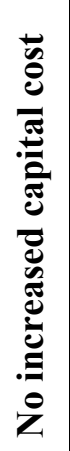 & 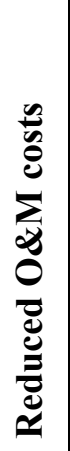 & 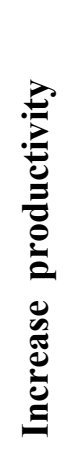 & 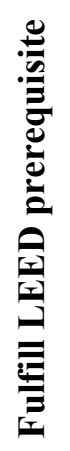 & 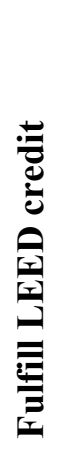 & 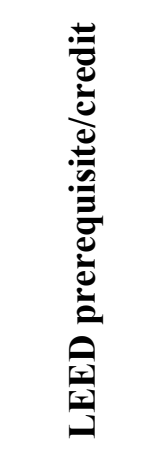 \\
\hline \multicolumn{8}{|l|}{ Efficient HVAC Systems } \\
\hline $\begin{array}{l}\text { - Use programmable thermostats in buildings without } \\
\text { automated building control systems }\end{array}$ & & $\checkmark$ & $\checkmark$ & & $\mathrm{C}$ & $\mathrm{C}$ & $\begin{array}{l}\text { EA PR 2, } \\
\text { EA CR } 1\end{array}$ \\
\hline $\begin{array}{l}\text { - Specify an economizer on roof-top units and economizer } \\
\text { controls on all HVAC systems }\end{array}$ & & $\checkmark$ & $\checkmark$ & $\checkmark$ & $\mathrm{C}$ & $\mathrm{C}$ & $\begin{array}{l}\text { EA PR 2, } \\
\text { EA CR } 1\end{array}$ \\
\hline - Use LNG for heating at the site & & & $\checkmark$ & & & & \\
\hline $\begin{array}{l}\text { Specify direct evaporative cooling whenever possible, } \\
\text { and indirect evaporative cooling where humidity could } \\
\text { be an issue }\end{array}$ & $\checkmark$ & & $\checkmark$ & & & & \\
\hline $\begin{array}{l}\text { - Use passive solar technologies to preheat outside air and } \\
\text { hot water }\end{array}$ & & & $\checkmark$ & & $\mathrm{C}$ & $\mathrm{C}$ & $\begin{array}{l}\text { EA PR 2, } \\
\text { EA CR } 1\end{array}$ \\
\hline \multicolumn{8}{|l|}{ Environmentally Friendly Refrigerants } \\
\hline $\begin{array}{l}\text { - Do not use CFC-based refrigerants in building HVAC } \\
\text { systems }\end{array}$ & & & & & $\mathrm{F}$ & & EA PR 3 \\
\hline \multicolumn{8}{|l|}{ Materials \& Resources } \\
\hline \multicolumn{8}{|l|}{ Promote Recycling } \\
\hline $\begin{array}{l}\text { - At a minimum, incorporate recycling stations in } \\
\text { building designs for all materials currently recycled }\end{array}$ & & & & & $\mathrm{C}$ & & MR PR 1 \\
\hline $\begin{array}{l}\text { - Consider vertical chutes to assist with collection in } \\
\text { multi-story buildings }\end{array}$ & & & & & & & \\
\hline $\begin{array}{l}\text { - Provide for future expansion of the recycling } \\
\text { program }\end{array}$ & & & & & & & \\
\hline
\end{tabular}

$\mathrm{C}=$ Contributes

$\mathrm{CR}=$ Credit

$\mathrm{EA}=$ Energy \& Atmosphere

$\mathrm{EQ}=$ Indoor Environmental Quality

$\mathrm{F}=$ Fulfills
$\mathrm{MR}=$ Materials \& Resources

$\mathrm{PR}=$ Prerequisite

$\mathrm{SS}=$ Sustainable Sites

$\mathrm{WE}=$ Water Efficiency

$\checkmark=$ Meets criteria 


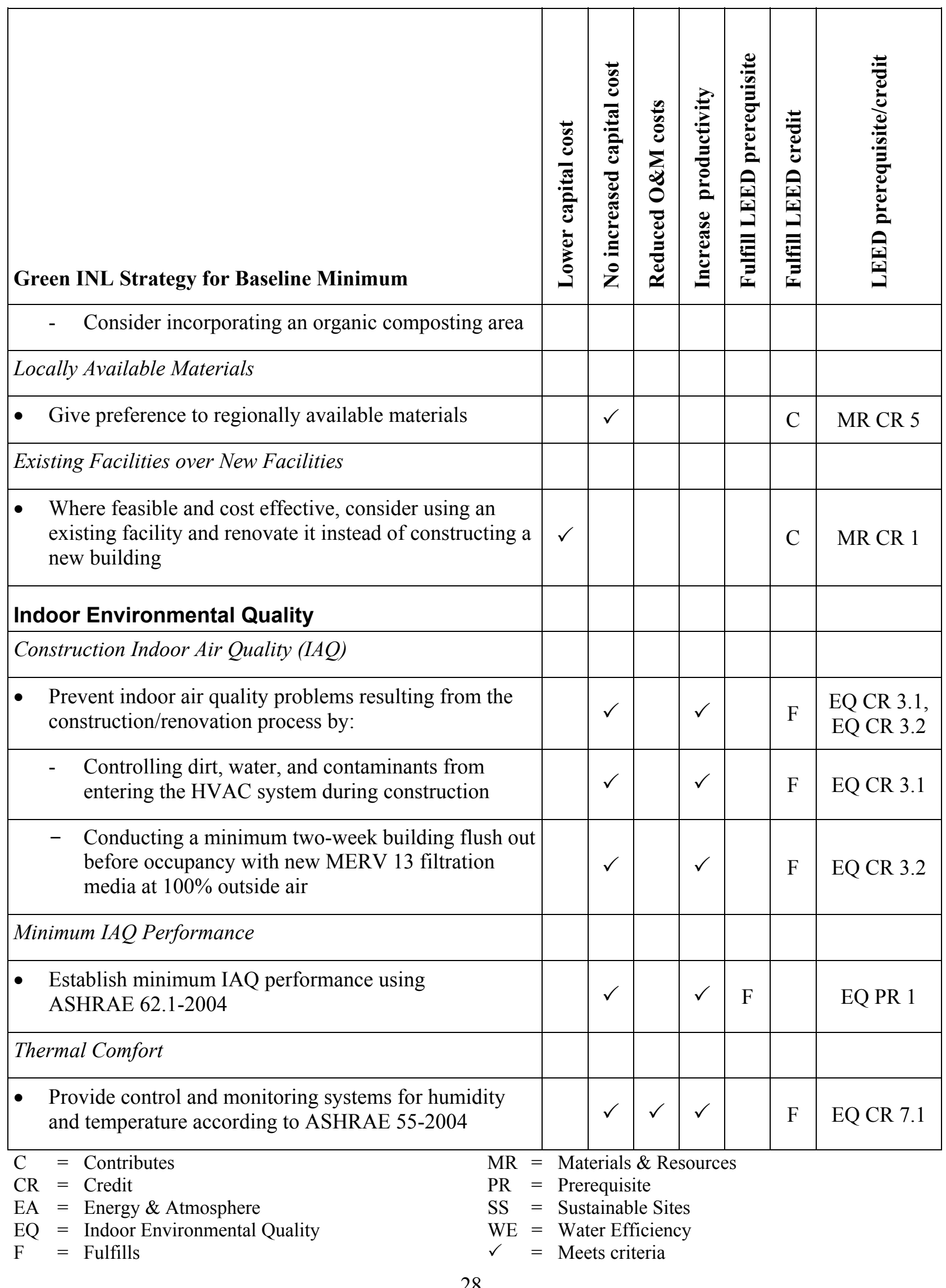




\begin{tabular}{|c|c|c|c|c|c|c|c|}
\hline Green INL Strategy for Baseline Minimum & 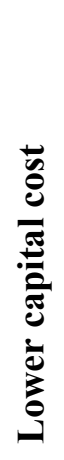 & 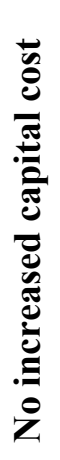 & 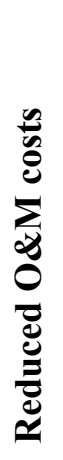 & 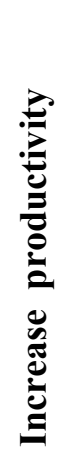 & 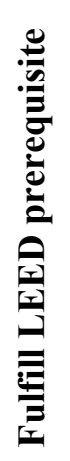 & 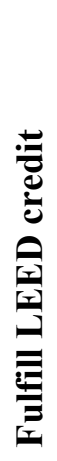 & 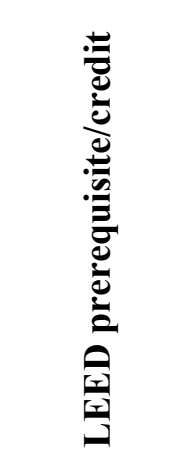 \\
\hline \multicolumn{8}{|l|}{ Outdoor Designated Smoking Areas } \\
\hline $\begin{array}{l}\text { Establish designated smoking areas outside the building } \\
\text { that are away and downwind from entryways, operable } \\
\text { windows, and air intakes }\end{array}$ & & & & & $\mathrm{F}$ & & EQ PR 2 \\
\hline \multicolumn{8}{|l|}{ Air Change Effectiveness } \\
\hline $\begin{array}{l}\text { - Use ASHRAE 129-1997 to confirm ventilation } \\
\text { effectiveness }\end{array}$ & & $\checkmark$ & $\checkmark$ & $\checkmark$ & & $\mathrm{F}$ & EQ CR 2 \\
\hline \multicolumn{8}{|l|}{ Low-Emitting Materials } \\
\hline $\begin{array}{l}\text { - Specify paints and coatings with low or no VOC content } \\
\text { and/or recycled content }\end{array}$ & $\checkmark$ & & & $\checkmark$ & & $\mathrm{C}$ & $\begin{array}{l}\text { EQ CR 4.2, } \\
\text { MR CR 4.1 }\end{array}$ \\
\hline
\end{tabular}

$\mathrm{C}=$ Contributes

$\mathrm{CR}=$ Credit

$\mathrm{EA}=$ Energy \& Atmosphere

$\mathrm{EQ}=$ Indoor Environmental Quality

$\mathrm{F}=$ Fulfills
$\mathrm{MR}=$ Materials \& Resources

$\mathrm{PR}=$ Prerequisite

$\mathrm{SS}=$ Sustainable Sites

$\mathrm{WE}=$ Water Efficiency

$\checkmark \quad=$ Meets criteria 


\section{LEED CERTIFICATION}

\begin{tabular}{|c|c|c|c|c|c|c|c|}
\hline Green INL Strategy for LEED Certification & 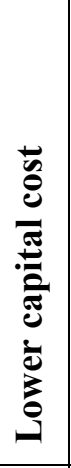 & 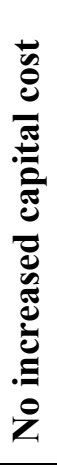 & 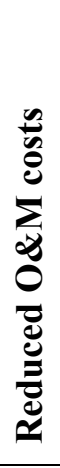 & 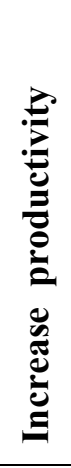 & 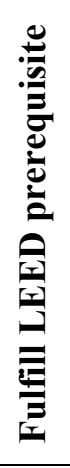 & 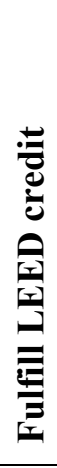 & 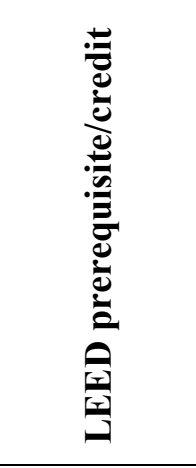 \\
\hline \multicolumn{8}{|l|}{ Sustainable Sites } \\
\hline \multicolumn{8}{|l|}{ Erosion \& Sedimentation Control } \\
\hline - Design a sediment and erosion control plan & & $\checkmark$ & & & $\mathrm{F}$ & & SS PR 1 \\
\hline \multicolumn{8}{|l|}{ Landscaping } \\
\hline $\begin{array}{l}\text { - Design a rainwater harvesting system with a gravity feed } \\
\text { system for irrigation }\end{array}$ & & & $\checkmark$ & & & $\mathrm{C}$ & WE CR 1.2 \\
\hline \multicolumn{8}{|l|}{ Stormwater Management } \\
\hline - Consider porous pavement in parking lots and walkways & & $\checkmark$ & & & & $\mathrm{C}$ & $\begin{array}{l}\text { SS CR 6.1, } \\
\text { SS CR 7.1 }\end{array}$ \\
\hline \multicolumn{8}{|l|}{ Reduced Site Disturbance } \\
\hline $\begin{array}{l}\text { - On greenfield sites, limit site disturbance beyond the } \\
\text { building perimeter }\end{array}$ & & $\checkmark$ & & & & $\mathrm{F}$ & SS CR 5.1 \\
\hline \multicolumn{8}{|l|}{ Water Efficiency } \\
\hline \multicolumn{8}{|l|}{ Low water fixtures } \\
\hline - Specify waterless urinals & $\checkmark$ & & $\checkmark$ & & & $\mathrm{C}$ & WE CR 3 \\
\hline - Consider dual flush water closets & & & $\checkmark$ & & & $\mathrm{C}$ & WE CR 3 \\
\hline $\begin{array}{l}\text { - Specify interior gray water collection for black water } \\
\text { use }\end{array}$ & & & & & & $\mathrm{C}$ & WE CR 2 \\
\hline - Use on-demand or point of use water heating & $\checkmark$ & & $\checkmark$ & $\checkmark$ & & $\mathrm{C}$ & $\begin{array}{l}\text { WE CR 3, } \\
\text { EA CR } 1\end{array}$ \\
\hline
\end{tabular}

$\mathrm{C}=$ Contributes

$\mathrm{CR}=$ Credit

$\mathrm{EA}=$ Energy \& Atmosphere

$\mathrm{EQ}=$ Indoor Environmental Quality

$\mathrm{F}=$ Fulfills
$\mathrm{MR}=$ Materials \& Resources

$\mathrm{PR}=$ Prerequisite

$\mathrm{SS}=$ Sustainable Sites

$\mathrm{WE}=$ Water Efficiency

$\checkmark \quad=$ Meets criteria 


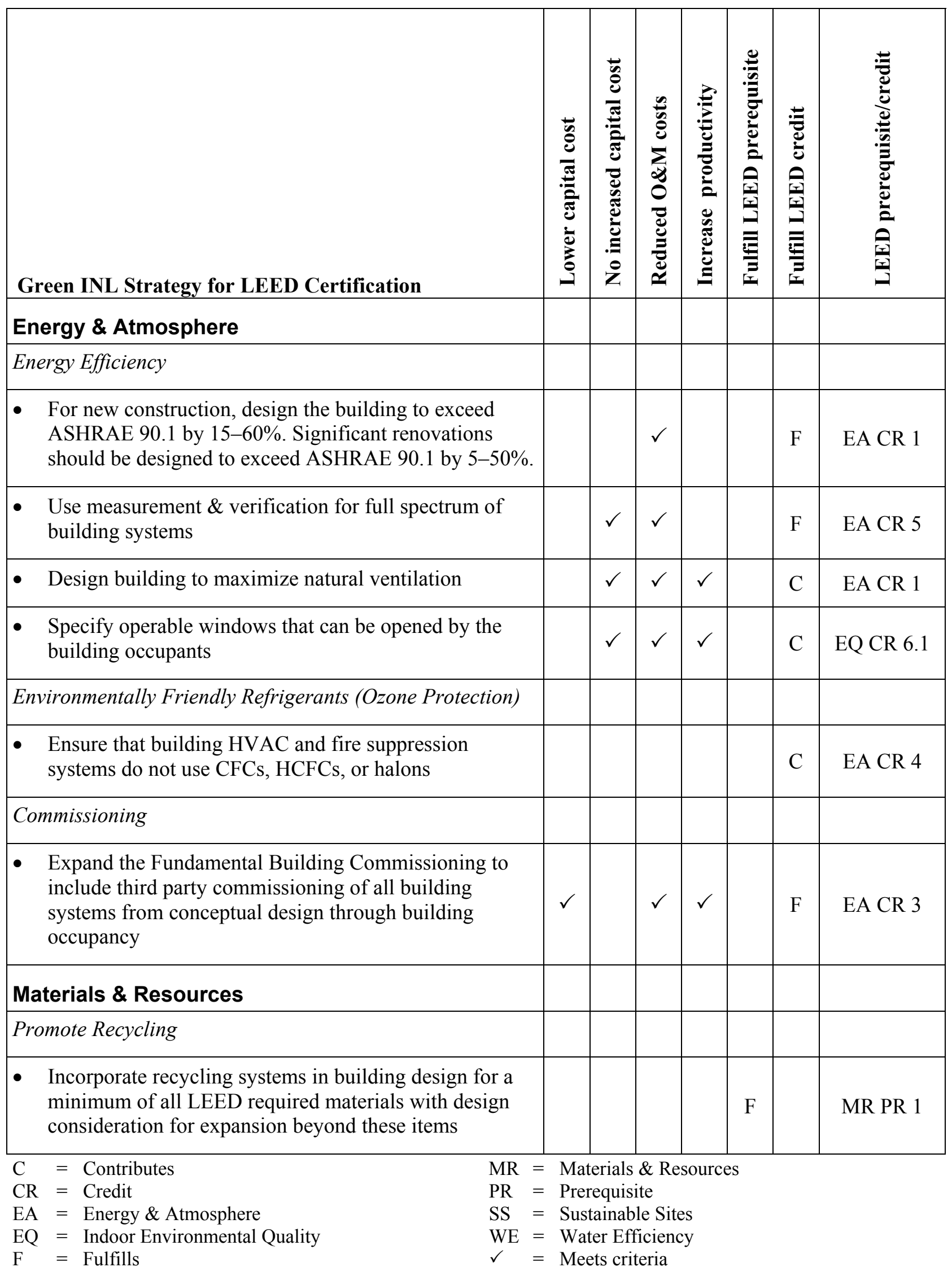




\begin{tabular}{|c|c|c|c|c|c|c|c|}
\hline Green INL Strategy for LEED Certification & 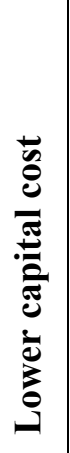 & 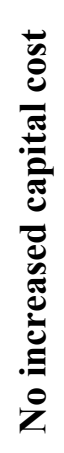 & 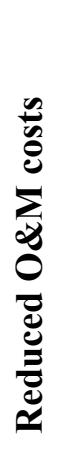 & 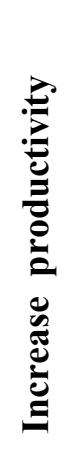 & 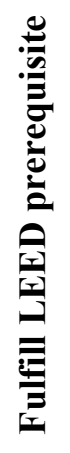 & 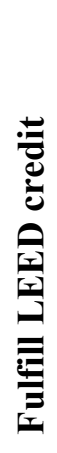 & 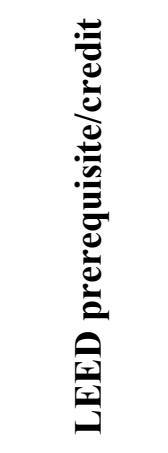 \\
\hline $\begin{array}{l}\text { - Consider vertical chutes to assist with collection in } \\
\text { multi-story buildings }\end{array}$ & & & & & & & \\
\hline $\begin{array}{l}\text { - Provide for future expansion of the recycling } \\
\text { program }\end{array}$ & & & & & & & \\
\hline \multicolumn{8}{|l|}{ Waste Minimization } \\
\hline $\begin{array}{l}\text { - Design with waste minimization in mind using } \\
\text { dimensions and configurations that will lead to less } \\
\text { material waste during construction }\end{array}$ & & $\checkmark$ & & & & & \\
\hline $\begin{array}{l}\text { - Develop methods to reduce waste during construction } \\
\text { and divert waste from the landfill }\end{array}$ & & $\checkmark$ & & & & $\mathrm{C}$ & MR CR 2 \\
\hline - Donate reusable construction waste to local charities & & $\checkmark$ & & & & $\mathrm{C}$ & MR CR 2 \\
\hline $\begin{array}{l}\text { Provide bins at the construction site for all } \\
\text { construction waste to be reused, recycled, and } \\
\text { salvaged/donated }\end{array}$ & & $\checkmark$ & & & & $\mathrm{C}$ & MR CR 2 \\
\hline $\begin{array}{l}\text { - Design with materials that serve multiple functions and } \\
\text { allow for omission of layers }\end{array}$ & $\checkmark$ & & & & & & \\
\hline $\begin{array}{l}\text { - Design using a flexible building floor plan to } \\
\text { accommodate changing floor plans in the future }\end{array}$ & & $\checkmark$ & $\checkmark$ & & & & \\
\hline \multicolumn{8}{|l|}{ Salvaged Materials } \\
\hline - Specify salvaged materials & $\checkmark$ & & & & & $\mathrm{F}$ & MR CR 3 \\
\hline $\begin{array}{l}\text { - Consider incorporation of INL historically relevant } \\
\text { salvaged "landmarks" }\end{array}$ & & $\checkmark$ & & & & & \\
\hline
\end{tabular}

$\mathrm{C}=$ Contributes

$\mathrm{CR}=$ Credit

$\mathrm{EA}=$ Energy \& Atmosphere

$\mathrm{EQ}=$ Indoor Environmental Quality

$\mathrm{F}=$ Fulfills
$\mathrm{MR}=$ Materials \& Resources

$\mathrm{PR}=$ Prerequisite

$\mathrm{SS}=$ Sustainable Sites

$\mathrm{WE}=$ Water Efficiency

$\checkmark=$ Meets criteria 


\begin{tabular}{|c|c|c|c|c|c|c|c|}
\hline Green INL Strategy for LEED Certification & 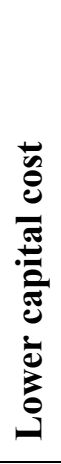 & 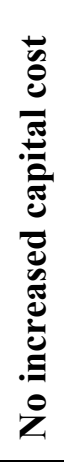 & 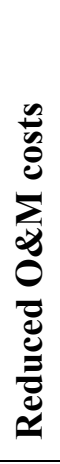 & 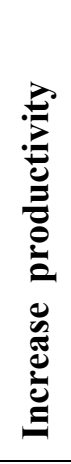 & 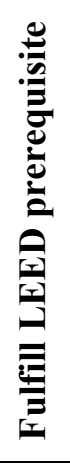 & 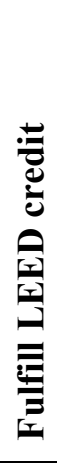 & 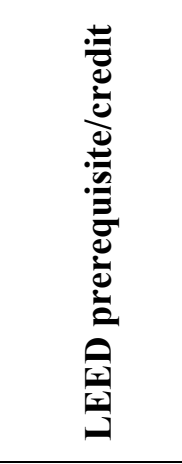 \\
\hline \multicolumn{8}{|l|}{ Recycled Materials } \\
\hline - Specify recycled content materials & & $\checkmark$ & & & & $\mathrm{F}$ & MR CR 4 \\
\hline \multicolumn{8}{|l|}{ Biobased and Rapidly Renewable Materials } \\
\hline $\begin{array}{l}\text { - Specify biobased products or products made from } \\
\text { rapidly renewable materials }\end{array}$ & & $\checkmark$ & & & & $\mathrm{F}$ & MR CR 6 \\
\hline \multicolumn{8}{|l|}{ Certified Wood } \\
\hline - Specify sustainably harvested wood & & $\checkmark$ & & & & $\mathrm{F}$ & MR CR 7 \\
\hline \multicolumn{8}{|l|}{ Indoor Environmental Quality } \\
\hline \multicolumn{8}{|l|}{ Indoor Air Quality } \\
\hline $\begin{array}{l}\text { - Incorporate carbon dioxide }\left(\mathrm{CO}_{2}\right) \text { monitoring systems } \\
\text { into automated building control systems }\end{array}$ & & & $\checkmark$ & $\checkmark$ & $\mathrm{C}$ & $\mathrm{F}$ & $\begin{array}{l}\text { EQ CR 1, } \\
\text { EA PR 2, } \\
\text { EA CR } 1\end{array}$ \\
\hline \multicolumn{8}{|l|}{ Low-Emitting Materials } \\
\hline $\begin{array}{l}\text { - Specify products with low or no volatile organic } \\
\text { compound (VOC) content for the following material } \\
\text { types: }\end{array}$ & & $\checkmark$ & & & & $\mathrm{F}$ & EQ CR 4 \\
\hline - $\quad$ Adhesives and sealants & & $\checkmark$ & & $\checkmark$ & & $\mathrm{F}$ & EQ CR 4.1 \\
\hline - $\quad$ Paints and coatings & & $\checkmark$ & & $\checkmark$ & & $\mathrm{F}$ & EQ CR 4.2 \\
\hline - $\quad$ Carpet systems & & $\checkmark$ & & $\checkmark$ & & $\mathrm{F}$ & EQ CR 4.3 \\
\hline - Composite wood and agrifiber products & & $\checkmark$ & & $\checkmark$ & & $\mathrm{F}$ & EQ CR 4.4 \\
\hline - Avoid materials made from vinyl or PVC & & & & & & & \\
\hline
\end{tabular}

$\mathrm{C}=$ Contributes

$\mathrm{CR}=$ Credit

$\mathrm{EA}=$ Energy \& Atmosphere

$\mathrm{EQ}=$ Indoor Environmental Quality

$\mathrm{F}=$ Fulfills
$\mathrm{MR}=$ Materials \& Resources

$\mathrm{PR}=$ Prerequisite

$\mathrm{SS}=$ Sustainable Sites

$\mathrm{WE}=$ Water Efficiency

$\checkmark=$ Meets criteria 
Appendix A

\begin{tabular}{|l|l|l|l|l|l|l|}
\hline & & & & & \\
\end{tabular}

$\mathrm{C}=$ Contributes

$\mathrm{CR}=$ Credit

$\mathrm{EA}=$ Energy \& Atmosphere

$\mathrm{EQ}=$ Indoor Environmental Quality

$\mathrm{F}=$ Fulfills
$\mathrm{MR}=$ Materials \& Resources

$\mathrm{PR}=$ Prerequisite

$\mathrm{SS}=$ Sustainable Sites

$\mathrm{WE}=$ Water Efficiency

$\checkmark \quad=$ Meets criteria 


\section{INNOVATIVE}

\begin{tabular}{|c|c|c|c|c|c|c|c|}
\hline Green INL Strategy for Innovative & 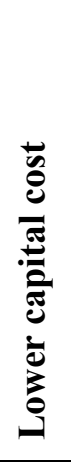 & 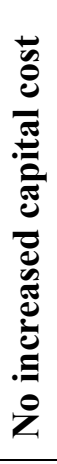 & 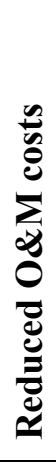 & 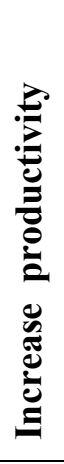 & 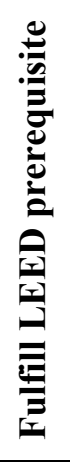 & 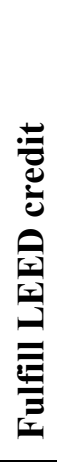 & 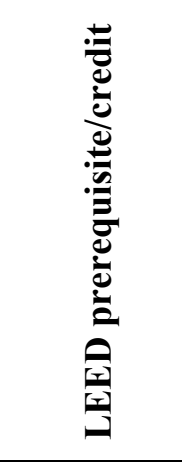 \\
\hline \multicolumn{8}{|l|}{ Sustainable Sites } \\
\hline \multicolumn{8}{|l|}{ Stormwater Collection } \\
\hline $\begin{array}{l}\text { - Design the roof to be partially or entirely composed of a } \\
\text { vegetated roof }\end{array}$ & & & & & & $\mathrm{C}$ & $\begin{array}{l}\text { SS CR 6.1, } \\
\text { SS CR 7.2 }\end{array}$ \\
\hline \multicolumn{8}{|l|}{ Alternative Transportation } \\
\hline $\begin{array}{l}\text { - Consider hydrogen as the primary fuel for intra-site } \\
\text { transportation }\end{array}$ & & & & & & $\mathrm{C}$ & SS CR 4.3 \\
\hline \multicolumn{8}{|l|}{ Water Efficiency } \\
\hline \multicolumn{8}{|l|}{ Low water fixtures } \\
\hline - Consider composting water closets & & & & & & $\mathrm{C}$ & $\begin{array}{l}\text { WE CR 2, } \\
\text { WE CR } 3\end{array}$ \\
\hline - Consider onsite wastewater treatment for town facilities & & & & & & $\mathrm{F}$ & WE CR 2 \\
\hline \multicolumn{8}{|l|}{ Energy \& Atmosphere } \\
\hline \multicolumn{8}{|l|}{ Energy Efficiency } \\
\hline $\begin{array}{l}\text { - Use a heat exchanger in buildings with separate } \\
\text { perimeter and core zones to take advantage of times } \\
\text { when the perimeter zone is heating and the core zone is } \\
\text { cooling }\end{array}$ & & $\checkmark$ & $\checkmark$ & & $\mathrm{C}$ & $\mathrm{C}$ & $\begin{array}{l}\text { EA PR 2, } \\
\text { EA CR } 1\end{array}$ \\
\hline - Design for $100 \%$ natural ventilation & & $\checkmark$ & $\checkmark$ & $\checkmark$ & $\mathrm{C}$ & $\mathrm{C}$ & $\begin{array}{l}\text { EA PR 2, } \\
\text { EA CR } 1\end{array}$ \\
\hline $\begin{array}{l}\text { - Use high-performance glazed windows that are ultra- } \\
\text { efficient }\end{array}$ & & $\checkmark$ & $\checkmark$ & & $\mathrm{C}$ & $\mathrm{C}$ & $\begin{array}{l}\text { EA PR 2, } \\
\text { EA CR } 1\end{array}$ \\
\hline
\end{tabular}

$\mathrm{C}=$ Contributes

$\mathrm{CR}=$ Credit

$\mathrm{EA}=$ Energy \& Atmosphere

$\mathrm{EQ}=$ Indoor Environmental Quality

$\mathrm{F}=$ Fulfills
$\mathrm{MR}=$ Materials \& Resources

$\mathrm{PR}=$ Prerequisite

$\mathrm{SS}=$ Sustainable Sites

$\mathrm{WE}=$ Water Efficiency

$\checkmark=$ Meets criteria 


\begin{tabular}{|c|c|c|c|c|c|c|c|}
\hline Green INL Strategy for Innovative & 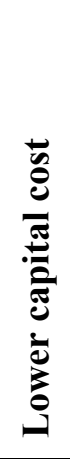 & 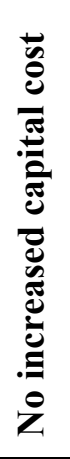 & 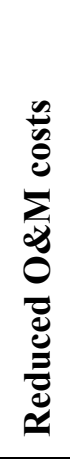 & 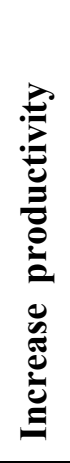 & 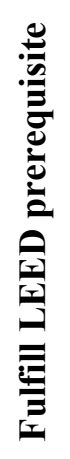 & 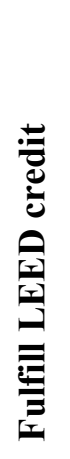 & 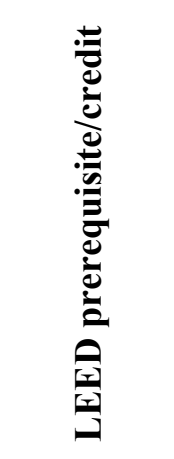 \\
\hline \multicolumn{8}{|l|}{ Alternative, Renewable Energy } \\
\hline $\begin{array}{l}\text { - Consider fuel cells for the building's entire electrical } \\
\text { demand }\end{array}$ & & & & & & $\mathrm{F}$ & EA CR 2 \\
\hline - Design for ground source heating and cooling & & & $\checkmark$ & & $\mathrm{C}$ & $\mathrm{C}$ & $\begin{array}{l}\text { EA PR 2, } \\
\text { EA CR } 1\end{array}$ \\
\hline $\begin{array}{l}\text { - Consider roof-top vertical axis wind generation for } \\
\text { supplemental electrical power }\end{array}$ & & & $\checkmark$ & & & $\mathrm{C}$ & EA CR 2 \\
\hline $\begin{array}{l}\text { - Consider photovoltaics for supplemental electrical } \\
\text { power }\end{array}$ & & & $\checkmark$ & & & $\mathrm{C}$ & EA CR 2 \\
\hline \multicolumn{8}{|l|}{ Efficient HVAC Systems } \\
\hline - Specify radiant floor embedded heating and cooling & & & $\checkmark$ & $\checkmark$ & $\mathrm{C}$ & $\mathrm{C}$ & $\begin{array}{l}\text { EA PR 2, } \\
\text { EA CR } 1\end{array}$ \\
\hline \multicolumn{8}{|l|}{ Efficient Lighting } \\
\hline $\begin{array}{l}\text { - Use automatic sensors and dimming controls for daylit } \\
\text { areas }\end{array}$ & & $\checkmark$ & $\checkmark$ & $\checkmark$ & $\mathrm{C}$ & $\mathrm{C}$ & $\begin{array}{l}\text { EA PR 2, } \\
\text { EA CR } 1\end{array}$ \\
\hline - Creatively incorporate LEDs and T-5 lamps & & $\checkmark$ & $\checkmark$ & & $\mathrm{C}$ & $\mathrm{C}$ & $\begin{array}{l}\text { EA PR 2, } \\
\text { EA CR } 1\end{array}$ \\
\hline \multicolumn{8}{|l|}{ Materials \& Resources } \\
\hline \multicolumn{8}{|l|}{ Local Materials } \\
\hline - Specify materials from Idaho & & $\checkmark$ & & & & $\mathrm{C}$ & MR CR 5 \\
\hline \multicolumn{8}{|l|}{ Life Cycle Cost Analysis } \\
\hline $\begin{array}{l}\text { - Use an accepted Life Cycle Cost analysis method for all } \\
\text { building material selections }\end{array}$ & $\checkmark$ & & $\checkmark$ & & & & \\
\hline
\end{tabular}

$\mathrm{C}=$ Contributes

$\mathrm{CR}=$ Credit

$\mathrm{EA}=$ Energy \& Atmosphere

$\mathrm{EQ}=$ Indoor Environmental Quality

$\mathrm{F}=$ Fulfills
$\mathrm{MR}=$ Materials \& Resources

$\mathrm{PR}=$ Prerequisite

$\mathrm{SS}=$ Sustainable Sites

$\mathrm{WE}=$ Water Efficiency

$\checkmark \quad=$ Meets criteria 
Appendix A

\begin{tabular}{|c|c|c|c|c|c|c|c|}
\hline Green INL Strategy for Innovative & 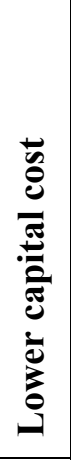 & 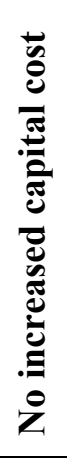 & 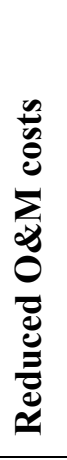 & 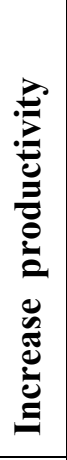 & 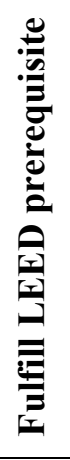 & 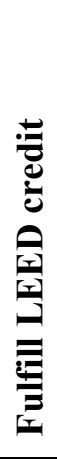 & 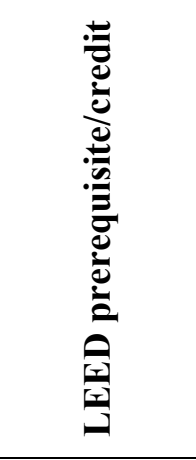 \\
\hline \multicolumn{8}{|l|}{ Closed Loop Material Selection } \\
\hline $\begin{array}{l}\text { - Design for deconstruction so that the building can be } \\
\text { disassembled into its constituent materials at the end of } \\
\text { its lifetime }\end{array}$ & & $\checkmark$ & & & & & \\
\hline \multicolumn{8}{|l|}{ Indoor Environmental Quality } \\
\hline \multicolumn{8}{|l|}{ Occupancy Comfort } \\
\hline $\begin{array}{l}\text { Provide individual lighting, temperature and air flow } \\
\text { controls to occupants via desktop personal computers }\end{array}$ & & & $\checkmark$ & $\checkmark$ & & $\mathrm{C}$ & $\begin{array}{l}\text { EQ CR 6.1, } \\
\text { EQ CR } 6.2\end{array}$ \\
\hline
\end{tabular}

$\mathrm{C}=$ Contributes

$\mathrm{CR}=$ Credit

$\mathrm{EA}=$ Energy \& Atmosphere

$\mathrm{EQ}=$ Indoor Environmental Quality

$\mathrm{F}=$ Fulfills
$\mathrm{MR}=$ Materials \& Resources

$\mathrm{PR}=$ Prerequisite

$\mathrm{SS}=$ Sustainable Sites

$\mathrm{WE}=$ Water Efficiency

$\checkmark \quad=$ Meets criteria 
Appendix B

\section{LEED 2.1 Certification Scoresheet}




\section{Appendix B}

\section{LEED 2.1 Certification Scoresheet}

LEED certification is the industry standard for evaluating the "greenness" of a building, including the surrounding site. Developed by the U.S. Green Building Council (USGBC), LEED measures the building's sustainable performance by focusing on the following five areas of sustainable design: Sustainable Sites, Water Efficiency, Energy and Atmosphere, Materials and Resources, and Indoor Environmental Quality. An additional category, Innovation and Design Process, gives a project team flexibility to get credit for using sustainable building practices not yet recognized in LEED, or exceeding an established LEED parameter.

Each category contains a number of sub-categories or credits. A point is earned for each credit that is met; some credits are further divided to offer additional points for meeting a parameter(s) beyond, or in addition to, the initial measurable accomplishment. A total of 69 possible points is available with four award levels for LEED 2.1 certification. These are:

- $\quad$ Certified (26-32 points)

- $\quad$ Silver (33-38 points)

- $\quad$ Gold (39-51 points)

- $\quad$ Platinum (52-69 points).

The USGBC considers a number of building practices essential to green building and has made them prerequisites for LEED certification. These prerequisites are baseline requirements for all buildings pursuing LEED certification, and they do not add points towards certification.

The next two pages show the LEED 2.1 scoresheet with the points that could be achieved if the strategies identified in this document are followed. The points achieved are broken down by each of the three levels of the INL Green Building Strategy: 1 for Baseline Minimum, 2 for LEED Certification, and 3 for Innovative.

The point summaries at the end of the scoresheet indicate that 12 points can be gained by adoption of Baseline Minimum features, an additional 30 points through the adoption of LEED Certification features, and another 7 points are possible for the adoption of the more complex Innovative features identified at this time. While a total of 42 points could be achieved if all of the strategies under Baseline Minimum and LEED Certification are followed qualifying for a building LEED Gold certification, it is likely that not all of the points identified will be earned. An example is the points for LEED E\&A Credit 1, Optimize Energy Performance; where the strategy under Level 2, LEED Certification, specifies exceeding the ASHRAE 90.1 Code by $15-60 \%$ for all new construction. This can result in 1 to 8 points towards LEED certification, depending on how much energy is saved (an additional point is awarded for every $5 \%$ beyond the minimum $15 \%$ efficiency). If only 1 point is awarded for meeting the minimum goal of this strategy, the total possible points decreases by 7 points for a possible 35 points. Therefore a LEED Silver certification is recommended, at a minimum, and considered most likely through the implementation of the INL Green Building Strategy.

This appendix has been prepared to give an example of how this document can lead to a potential certification. The LEED 2.1 Reference Manual should be used during design to verify that the full criteria of the point have been met.

Additional documentation will need to be prepared as part of the certification package submitted to the USGBC. 
Appendix B 
$\begin{array}{lll}1 & 2 & 3\end{array}$

Credit 4.1 Alternative Transportation, Public Transportation Access

Credit 4.2 Alternative Transportation, Bicycle Storage \& Changing Rooms

Credit 4.3 Alternative Transportation, Alternative Fuel Vehicles

Credit 4.4 Alternative Transportation, Parking Capacity and Carpooling

Credit 5.1 Reduced Site Disturbance, Protect or Restore Open Space

Credit 5.2 Reduced Site Disturbance, Development Footprint

Credit 6.1 Stormwater Management, Rate and Quantity

Credit 6.2 Stormwater Management, Treatment

Credit 7.1 Landscape \& Exterior Design to Reduce Heat Islands, Non-Roof

Credit 7.2 Landscape \& Exterior Design to Reduce Heat Islands, Roof

Credit 8 Light Pollution Reduction

Preq 3 CFC Reduction in HVAC\&R Equipment

Credit 1 Optimize Energy Performance

Credit 2.1 Renewable Energy, 5\%

Credit 2.2 Renewable Energy, 10\%

Credit 2.3 Renewable Energy, 20\%

Credit 3 Additional Commissioning

Credit 4 Ozone Depletion

Credit 5 Measurement \& Verification

Credit 6 Green Power 
Credit 1.1 Building Reuse, Maintain $75 \%$ of Existing Shell

Credit 1.2 Building Reuse, Maintain $100 \%$ of Shell

Credit 1.3 Building Reuse, Maintain 100\% Shell \& 50\% Non-Shell

Credit 2.1 Construction Waste Management, Divert 50\%

Credit 2.2 Construction Waste Management, Divert 75\%

Credit 3.1 Resource Reuse, Specify 5\%

Credit 3.2 Resource Reuse, Specify $10 \%$

Credit 4.1 Recycled Content, Specify 5\% (post-consumer + 1/2 post-industrial)

Credit 4.2 Recycled Content, Specify 10\% (post-consumer + 1/2 post-industrial)

Credit 5.1 Local/Regional Materials, 20\% Manufactured Locally

Credit 5.2 Local/Regional Materials, of 20\% Above, $50 \%$ Harvested Locally

Credit 6 Rapidly Renewable Materials

Credit 7 Certified Wood

\section{Credit 1 Carbon Dioxide $\left(\mathrm{CO}_{2}\right)$ Monitoring}

Credit 2 Ventilation Effectiveness

Credit 3.1 Construction IAQ Management Plan, During Construction

Credit 3.2 Construction IAQ Management Plan, Before Occupancy

Credit 4.1 Low-Emitting Materials, Adhesives \& Sealants

Credit 4.2 Low-Emitting Materials, Paints

Credit 4.3 Low-Emitting Materials, Carpet

Credit 4.4 Low-Emitting Materials, Composite Wood \& Agrifiber

Credit 5 Indoor Chemical \& Pollutant Source Control

Credit 6.1 Controllability of Systems, Perimeter

Credit 6.2 Controllability of Systems, Non-Perimeter

Credit 7.1 Thermal Comfort, Comply with ASHRAE 55-1992

Credit 7.2 Thermal Comfort, Permanent Monitoring System

Credit 8.1 Daylight \& Views, Daylight $75 \%$ of Spaces

Credit 8.2 Daylight \& Views, Views for $90 \%$ of Spaces

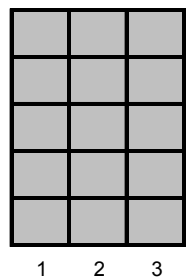

Innovation \& Design Process

Credit 1.1 Innovation in Design: Provide Specific Title

Credit 1.2 Innovation in Design: Provide Specific Title

Credit 1.3 Innovation in Design: Provide Specific Title

Credit 1.4 Innovation in Design: Provide Specific Title

Credit 2 LEED ${ }^{\text {TM }}$ Accredited Professional 